Biogeosciences, 10, 1983-2000, 2013

www.biogeosciences.net/10/1983/2013/

doi:10.5194/bg-10-1983-2013

(C) Author(s) 2013. CC Attribution 3.0 License.

\title{
Global ocean carbon uptake: magnitude, variability and trends
}

\author{
R. Wanninkhof ${ }^{1}$, G. -H. Park ${ }^{1,2, *}$, T. Takahashi ${ }^{3}$, C. Sweeney $^{4,16}$, R. Feely ${ }^{5}$, Y. Nojiri ${ }^{6}$, N. Gruber ${ }^{7}$, S. C. Doney ${ }^{8}$, \\ G. A. McKinley ${ }^{9}$, A. Lenton ${ }^{10}$, C. Le Quéré ${ }^{11}$, C. Heinze ${ }^{12,13,14}$, J. Schwinger ${ }^{12,13}$, H. Graven ${ }^{7,15}$, and S. Khatiwala ${ }^{3}$ \\ ${ }^{1}$ Ocean Chemistry Division, NOAA/AOML, 4301 Rickenbacker Causeway, Miami, FL 33149, USA \\ ${ }^{2}$ Cooperative Institute for Marine and Atmospheric Studies, University of Miami, Miami, FL 33149, USA \\ ${ }^{3}$ Lamont-Doherty Earth Observatory of Columbia University, Route 9W, Palisades, NY 10964, USA \\ ${ }^{4}$ NOAA/ESRL Carbon Cycle Group Aircraft Project Lead, 325 Broadway GMD/1, Boulder, CO 80304, USA \\ ${ }^{5}$ Ocean Climate Research Division, NOAA/PMEL, 7600 Sand Point Way NE, Seattle, WA 98115, USA \\ ${ }^{6}$ Center for Global Environmental Research National Institute for Environmental Studies Onogawa 16-2, Tsukuba, \\ Ibaraki 305-8506, Japan \\ ${ }^{7}$ Environmental Physics Group, Institute of Biogeochemistry and Pollutant Dynamics, ETH Zurich, 8092 Zurich, Switzerland \\ ${ }^{8}$ Woods Hole Oceanographic Institution, Woods Hole, MA 02543, USA \\ ${ }^{9}$ Atmospheric and Oceanic Sciences and Center for Climatic Research, University of Wisconsin - Madison, WI 53706, USA \\ ${ }^{10}$ CSIRO Marine and Atmospheric Research, P.O. BOX 1538 Hobart Tasmania, Australia \\ ${ }^{11}$ Tyndall Centre for Climate Change Research, University of East Anglia, Norwich Research Park, Norwich NR4 7TJ, UK \\ ${ }^{12}$ Geophysical Institute, University of Bergen, Allegaten 70, 5007 Bergen, Norway \\ ${ }^{13}$ Bjerknes Centre for Climate Research, Bergen, Norway \\ ${ }^{14}$ Uni Bjerknes Centre, Uni Research, Bergen, Norway \\ ${ }^{15}$ Scripps Institution of Oceanography, University of California San Diego, 9500 Gilman Dr., La Jolla, CA 92093, USA \\ ${ }^{16}$ CIRES, University of Colorado, Boulder, CO 80304, USA \\ * now at: East Sea Research Institute, Korea Institute of Ocean Science \& Technology, Uljin, 767-813, Korea
}

Correspondence to: R. Wanninkhof (rik.wanninkhof@ noaa.gov)

Received: 30 June 2012 - Published in Biogeosciences Discuss.: 15 August 2012

Revised: 1 March 2013 - Accepted: 4 March 2013 - Published: 22 March 2013

\begin{abstract}
The globally integrated sea-air anthropogenic carbon dioxide $\left(\mathrm{CO}_{2}\right)$ flux from 1990 to $2009 \mathrm{r}$ is determined from models and data-based approaches as part of the Regional Carbon Cycle Assessment and Processes (RECCAP) project. Numerical methods include ocean inverse models, atmospheric inverse models, and ocean general circulation models with parameterized biogeochemistry (OBGCMs). The median value of different approaches shows good agreement in average uptake. The best estimate of anthropogenic $\mathrm{CO}_{2}$ uptake for the time period based on a compilation of approaches is $-2.0 \mathrm{PgC}^{-1}$. The interannual variability in the sea-air flux is largely driven by large-scale climate re-organizations and is estimated at $0.2 \mathrm{Pg} \mathrm{Cyr}^{-1}$ for the two decades with some systematic differences between approaches. The largest differences between approaches are seen in the decadal trends. The trends range from -0.13 $\left(\mathrm{Pg} \mathrm{C} \mathrm{yr}^{-1}\right)$ decade $^{-1}$ to $-0.50\left(\mathrm{PgC}_{\mathrm{yr}}{ }^{-1}\right)$ decade $^{-1}$ for the
\end{abstract}

two decades under investigation. The OBGCMs and the databased sea-air $\mathrm{CO}_{2}$ flux estimates show appreciably smaller decadal trends than estimates based on changes in carbon inventory suggesting that methods capable of resolving shorter timescales are showing a slowing of the rate of ocean $\mathrm{CO}_{2}$ uptake. RECCAP model outputs for five decades show similar differences in trends between approaches.

\section{Introduction}

The global analysis of sea-air carbon dioxide $\left(\mathrm{CO}_{2}\right)$ fluxes is part of the Regional Carbon Cycle Assessment and Processes (RECCAP) project that assesses the input of anthropogenic $\mathrm{CO}_{2}$ into the atmosphere (Andres et al., 2012) and the fluxes of carbon between the ocean, atmosphere and terrestrial biosphere from 1990 to 2009. While RECCAP aims to provide 
comprehensive assessments of carbon flows between the major labile reservoirs, data contributions and model output are provided on volunteer basis and for a set time period (19902009). Therefor not all major ocean models are represented; most notably some of the more advanced models runs for the Fifth Assessment Report (AR5) of the United Nations Intergovernmental Panel on Climate Change (IPCC) are not included. However, an appreciable number of different model outputs are used and the range of results for the different model types are representative.

The ocean exchanges $\mathrm{CO}_{2}$ with the atmosphere at the seaair interface. The exchange is driven by complex and varying physical and biogeochemical processes that make accurate assessment of the sea-air $\mathrm{CO}_{2}$ flux challenging. Knowledge of the exchange is important for several processes. The magnitude and direction of fluxes are indicative of biogeochemical cycling in the ocean. Estimates of the globally integrated sea-air fluxes are relevant for quantifying the ocean uptake of anthropogenic $\mathrm{CO}_{2}$ (Sabine and Tanhua, 2010).

The anthropogenic $\mathrm{CO}_{2}$ perturbation of the ocean is caused by increasing atmospheric $\mathrm{CO}_{2}$ levels due to fossil fuel burning and land use changes. It is superimposed on the natural $\mathrm{CO}_{2}$ cycle. While these can be separated in models, measurements provide the combined natural and anthropogenic component. Exchange of natural $\mathrm{CO}_{2}$ across the sea-air interface tends to dominate on regional scales (Gruber et al., 2009) but largely cancels at the global scale. The exception is the outgassing of $\mathrm{CO}_{2}$ from the ocean that is driven by the input of carbon by rivers (Sarmiento and Sundquist, 1992). The global contemporary flux of $\mathrm{CO}_{2}$ is the sum of a natural $\mathrm{CO}_{2}$ flux, including the river-induced outgassing flux, and the anthropogenic $\mathrm{CO}_{2}$ uptake. Both natural and anthropogenic fluxes vary with time. The anthropogenic $\mathrm{CO}_{2}$ flux primarily responds to the increase in atmospheric $\mathrm{CO}_{2}$, with climate variability having a minor impact (e.g., Lovenduski et al., 2008). In contrast, the natural carbon flux is not impacted by the rise in atmospheric $\mathrm{CO}_{2}$, but can change substantially in response to climate (Le Quéré et al., 2010).

Different approaches are used to estimate the ocean carbon sink. The net sea-air $\mathrm{CO}_{2}$ flux across the sea-air interface provides a direct estimate of the contemporary flux. Micrometeorological techniques such as the eddy-covariance flux method (Fairall et al., 2000) can determine the sea-air $\mathrm{CO}_{2}$ fluxes directly at local scale but with significant uncertainty, preventing a meaningful extrapolation to larger scales. At regional to global scale, a bulk flux expression that has a kinetic term and a thermodynamic term is used to determine sea-air $\mathrm{CO}_{2}$ fluxes according to

$F=k \times\left(C_{\mathrm{w}}-C_{\mathrm{a}}\right)$,

where the kinetic term, $k$, is the gas transfer velocity and incorporates all processes that control the kinetics of the gas transfer across the sea-air interface. The term $\left(C_{\mathrm{w}}-C_{\mathrm{a}}\right)$ is the concentration gradient of the gas in the liquid boundary layer that is on the order of 100 micron thick. For sea-air $\mathrm{CO}_{2}$ fluxes, the equation is commonly written in terms of the partial pressure (or fugacity) difference across the interface according to

$F=k \times K_{0} \times\left(p \mathrm{CO}_{2 \mathrm{w}}-p \mathrm{CO}_{2 \mathrm{a}}\right)=k \times K_{0} \times \Delta p \mathrm{CO}_{2}$

where, by convention, the net flux into the ocean is expressed as negative value. $p \mathrm{CO}_{2 \mathrm{w}}$ is the partial pressure of $\mathrm{CO}_{2}$ of surface water, $p \mathrm{CO}_{2 \mathrm{a}}$ is the partial pressure of $\mathrm{CO}_{2}$ in air, $K_{0}$ is the solubility of $\mathrm{CO}_{2}$, and $\Delta p \mathrm{CO}_{2}$ is the partial pressure gradient $\left(\Delta p \mathrm{CO}_{2}=p \mathrm{CO}_{2 \mathrm{w}}-p \mathrm{CO}_{2 \mathrm{a}}\right)$. The $\mathrm{CO}_{2}$ levels in air are reported as a mixing ratio or mole fraction, $\mathrm{XCO}_{2 \mathrm{a}}$, which are converted to a partial pressure through $p \mathrm{CO}_{2 \mathrm{a}}=\mathrm{XCO}_{2 \mathrm{a}}$ $\left(P-p_{\mathrm{H}_{2} \mathrm{O}}\right)$, where $P$ is the ambient pressure and $p_{\mathrm{H}_{2} \mathrm{O}}$ is the saturation pressure of water vapor.

The principal observational approach to estimate the seaair flux of $\mathrm{CO}_{2}$ is to make measurements of $\Delta p \mathrm{CO}_{2}$ from ships and moorings and to use a parameterization of $k$ as a function of wind speed. Other approaches used to infer global sea-air $\mathrm{CO}_{2}$ fluxes rely on models, total dissolved inorganic carbon (DIC) measurements in the ocean interior and/or atmospheric data. Of these methods, those relying on simulations with Ocean General Circulation Models with parameterization of biogeochemical processes (OBGCMs) calculate the $\mathrm{CO}_{2}$ flux using Eq. (2). In this case, $p \mathrm{CO}_{2 \mathrm{w}}$ is computed from the modeled state variables of the carbonate system; total alkalinity (TAlk) and DIC. The resolution of global biogeochemical models used in RECCAP are on the order 2 by $2^{\circ}$ with output provided at monthly timescales. Ocean inverse models constrain the regional and global fluxes from interior ocean circulation and ocean interior data based on measurements of DIC and other tracers (Mikaloff Fletcher et al., 2006, 2007; Gruber et al., 2009). The ocean inverse models provide both the natural and anthropogenic $\mathrm{CO}_{2}$ flux components on decadal scales. The inverse estimates are independent of the estimates based on $\Delta p \mathrm{CO}_{2}$ (Eq. 2). Khatiwala et al. $(2009,2012)$ provide estimates of changes in anthropogenic $\mathrm{CO}_{2}$ in the ocean interior using a Green function with transient tracers that yields the anthropogenic $\mathrm{CO}_{2}$ uptake estimates at regional scales. Atmospheric inversions use atmospheric transport models and measured atmospheric $\mathrm{CO}_{2}$ levels to assess sources and sinks of contemporary $\mathrm{CO}_{2}$. The faster atmospheric transport and mixing compared to ocean circulation leads to coarser spatial resolution but higher temporal resolution compared to ocean inversions. The atmospheric inverse models used here resolve about a dozen ocean regions (Jacobson et al., 2007). Trends in the atmospheric ratio of $\mathrm{O}_{2} / \mathrm{N}_{2}$ along with atmospheric $\mathrm{CO}_{2}$ levels can be used to separate terrestrial $\mathrm{CO}_{2}$ uptake from that of oceanic uptake due to reservoir specific fractionation (Manning and Keeling, 2006; Bender et al., 2005). Scales of ocean uptake estimates from $\mathrm{O}_{2} / \mathrm{N}_{2}$ are hemispheric and seasonal.

Data-based estimates of variability and trends in ocean $\mathrm{CO}_{2}$ uptake are limited by the short record of observations. High quality measurements of $\mathrm{CO}_{2}$ in the surface water 
and air commenced in the early 1960's but at limited scope (Fig. 1). Global physical forcing fields such as wind speeds are available for the last 5 decades, but the older estimates are not always consistent with current measurements due to large changes in observing and interpolation methods.

Here the focus is on the last $20 \mathrm{yr}(1990-2009)$ with an emphasis is on an empirical approach that utilizes the $\Delta p \mathrm{CO}_{2}$ climatology and surface ocean temperature to estimate $p \mathrm{CO}_{2}$ variability. The global sea-air $\mathrm{CO}_{2}$ flux derived from this method is compared with models and other approaches. The background section is a summary of reported global sea-air $\mathrm{CO}_{2}$ fluxes and their uncertainties. The results of the $50 \mathrm{yr}$ runs of several of the OBGCMs are used to show the variability and trends in the ocean uptake. The methodology section provides an overview of how the sea-air fluxes are determined for the different approaches. An empirical approach is detailed to estimate a $20 \mathrm{yr}$ time series of globally integrated sea-air fluxes from the global $p \mathrm{CO}_{2}$ climatology, sea surface temperature (SST) and wind anomalies over the past two decades. The section also outlines the different models and other approaches used in the analysis. The discussion is focused on the anthropogenic $\mathrm{CO}_{2}$ flux and details the adjustments applied to the different modeling and observational approaches to get consistent estimates. In the last section the estimates are reconciled to provide a consistent global anthropogenic $\mathrm{CO}_{2}$ uptake. It concludes with a summary of the median anthropogenic $\mathrm{CO}_{2}$ uptake, and the subannual variability (SAV) and interannual variability (IAV) of the sea-air $\mathrm{CO}_{2}$ fluxes determined by the methods.

\section{Background}

\subsection{Atmospheric $\mathrm{CO}_{2}$ variability and trends}

The $p \mathrm{CO}_{2}$ of air $\left(p \mathrm{CO}_{2 \mathrm{a}}\right)$ is well constrained from measurement of the mole fraction of $\mathrm{CO}_{2}, \mathrm{XCO}_{2}$, in air at about 80 global flask sampling stations worldwide (Conway et al., 1994). Seasonal changes of approximately $10 \mathrm{ppm}$ over the Northern Hemisphere oceans are driven by the photosynthesis and respiration cycle of the terrestrial biosphere. Much smaller seasonal changes are observed in the Southern Hemisphere due to the lack of land cover. The atmospheric $\mathrm{CO}_{2}$ measurements point towards rapid zonal atmospheric mixing (weeks to month) and impedance in the tropics causing slower interhemispheric exchanges on the order of a year (Denning et al., 2002). Superimposed on the natural cycle is the increase in $\mathrm{CO}_{2}$ concentration from burning of fossil fuel and land use changes, the anthropogenic perturbation. The releases occur in the Northern Hemisphere with exchange of the excess $\mathrm{CO}_{2}$ to the Southern Hemisphere on annual timescales, leading to a substantial north-to-south gradient in the annual mean $\mathrm{XCO}_{2}$. Roughly half of the anthropogenic $\mathrm{CO}_{2}$ emissions accumulate in the atmosphere with the remainder taken up by the ocean and the terrestrial biosphere.

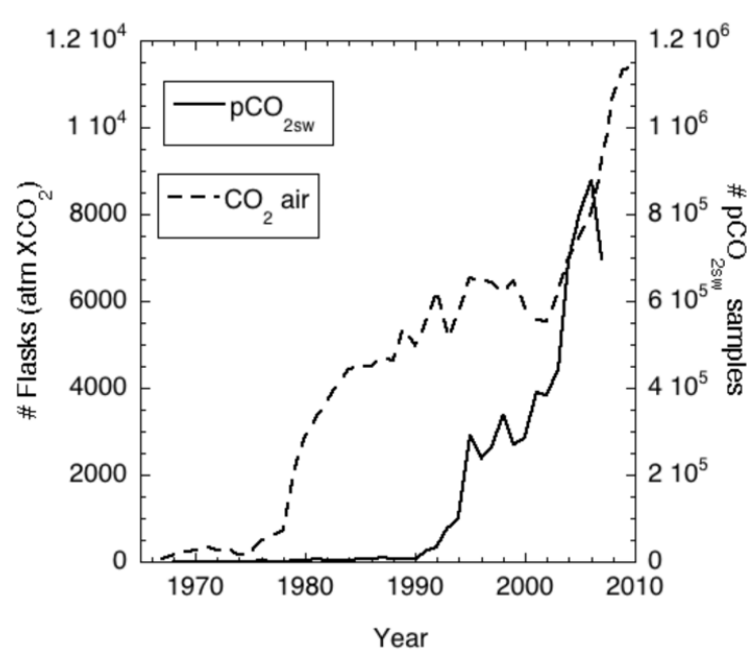

Fig. 1. Tabulation of the number of air $\mathrm{CO}_{2}$ samples (dashed line, left axis) and surface water $p \mathrm{CO}_{2}$ samples (solid line, right axis) taken per year. The tabulations for air samples are from NOAA/ESRL/GMD (courtesy T. Conway, NOAA/Earth System Research Laboratory/Global Monitoring Division) and the numbers of $p \mathrm{CO}_{2}$ surface water samples are from the SOCAT (Surface Ocean $\mathrm{CO}_{2}$ Atlas) database (Pfeil et al., 2012). Note the hundredfold difference in the scales of the left and right axes.

The global average increase in atmospheric $\mathrm{CO}_{2}$ concentration is $1.8 \mathrm{ppm} \mathrm{yr}^{-1}$ from 1990 to 2009.

\subsection{Oceanic $p \mathrm{CO}_{2 w}$ variability and trends}

In contrast to the $p \mathrm{CO}_{2}$ over the ocean, the $p \mathrm{CO}_{2}$ in the surface ocean $\left(p \mathrm{CO}_{2 \mathrm{w}}\right)$ is spatially and temporally more variable, and therefore requires several orders of magnitude more data to map variations (Figs. 1 and 2). Seasonal and interannual changes in the surface ocean can be $100 \mu$ atm or more. The spatial decorrelation length scales are on the order of $100 \mathrm{~s}$ of $\mathrm{km}$ (Li et al., 2005) compared to 1000s of $\mathrm{km}$ in the marine atmosphere. The greater variability and challenges in making measurements of $p \mathrm{CO}_{2 \mathrm{w}}$ means that for large parts of the ocean there are insufficient observations to obtain direct estimates of $\Delta p \mathrm{CO}_{2}$ (Fig. 2). Only select regions such as the equatorial Pacific, and time-series stations in the subtropical North Atlantic (ESTOC (European Time Series in the Canary Islands) and BATS (Bermuda Atlantic Time Series)) and subtropical North Pacific (HOT (Hawaii Ocean Timeseries)) have sufficient measurements and robust interpolation schemes to discern decadal variability and trends based on observations alone.

Two observational approaches have been pursued to overcome this data limitation. One is to collate the data to form a monthly global climatology of $\Delta p \mathrm{CO}_{2}$ (Takahashi et al., 2009), henceforth referred to as T-09. The T-09 climatology is constructed from approximately 3 million data points obtained over the last $40 \mathrm{yr}$, assuming that the $\Delta p \mathrm{CO}_{2}$ does not 

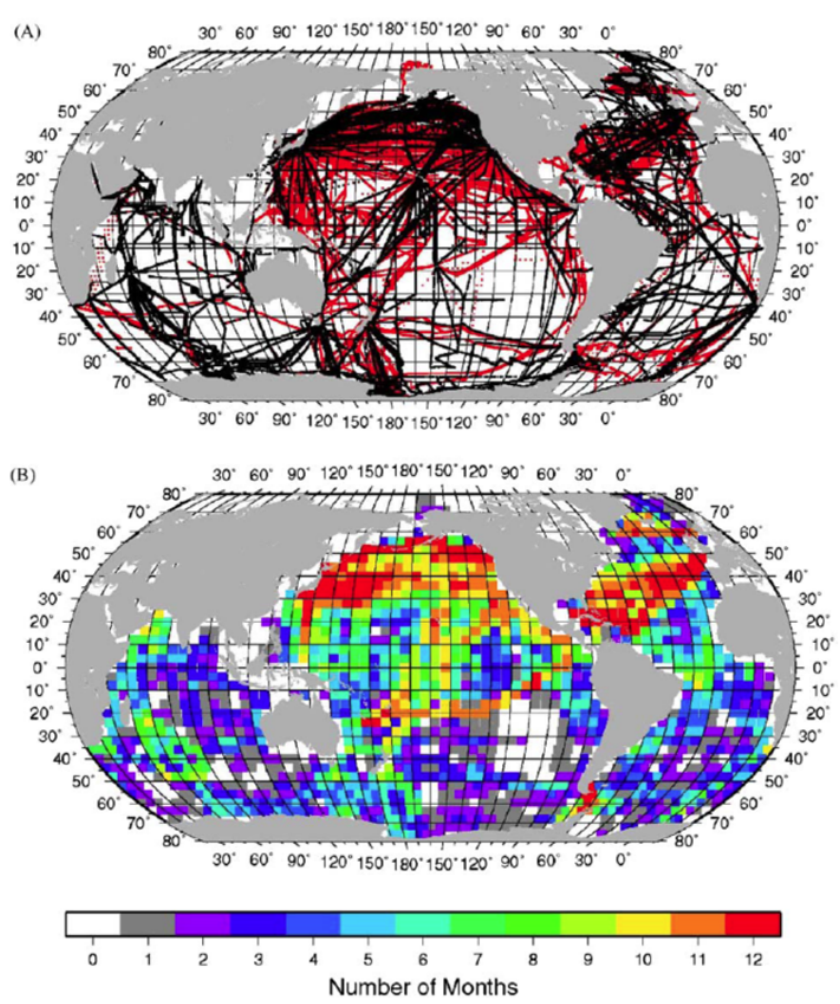

Fig. 2. (a) Cruise tracks with surface water $p \mathrm{CO}_{2}$ measurements. The black lines indicate the tracks with measurements used in Takahashi et al. (2002) and the red lines are measurements added to the database in Takahashi et al. (2009). (b) Number of months in each $4^{\circ}$ by $5^{\circ}$ area where at least one surface water $p \mathrm{CO}_{2}$ measurement has been made since the early 1970s. White areas are pixels that have no measurements. Reproduced from Fig. 1 in Takahashi et al. (2009).

vary on multiyear timescales. The climatology is on coarse ( $4^{\circ}$ latitude $\times 5^{\circ}$ longitude) resolution, and data have been interpolated over the annual cycle and in space using the mean surface flow fields from an OBGCM. The second approach is to interpolate the data in time and space using ancillary observations, such as SST, mixed layer depth and other surface parameters. No global estimate is yet available based on this approach, but regionally self-organizing maps (Telszewski et al., 2009) and multiparameter regressions (Schuster et al., 2013; Ishii et al., 2013) have been used to determine regional $\triangle p \mathrm{CO}_{2}$ fields and fluxes.

For variability and trends in $p \mathrm{CO}_{2 \mathrm{w}}$ over the past two decades we are limited to numerical models and a scheme that utilizes the monthly $p \mathrm{CO}_{2}$ climatology of T-09 and local-scale empirical relationships of $p \mathrm{CO}_{2 \mathrm{w}}$ against SST. These empirical relationships are then applied to the more comprehensive, time-varying SST record to arrive at monthly estimates (Park et al., 2010a) as detailed below.
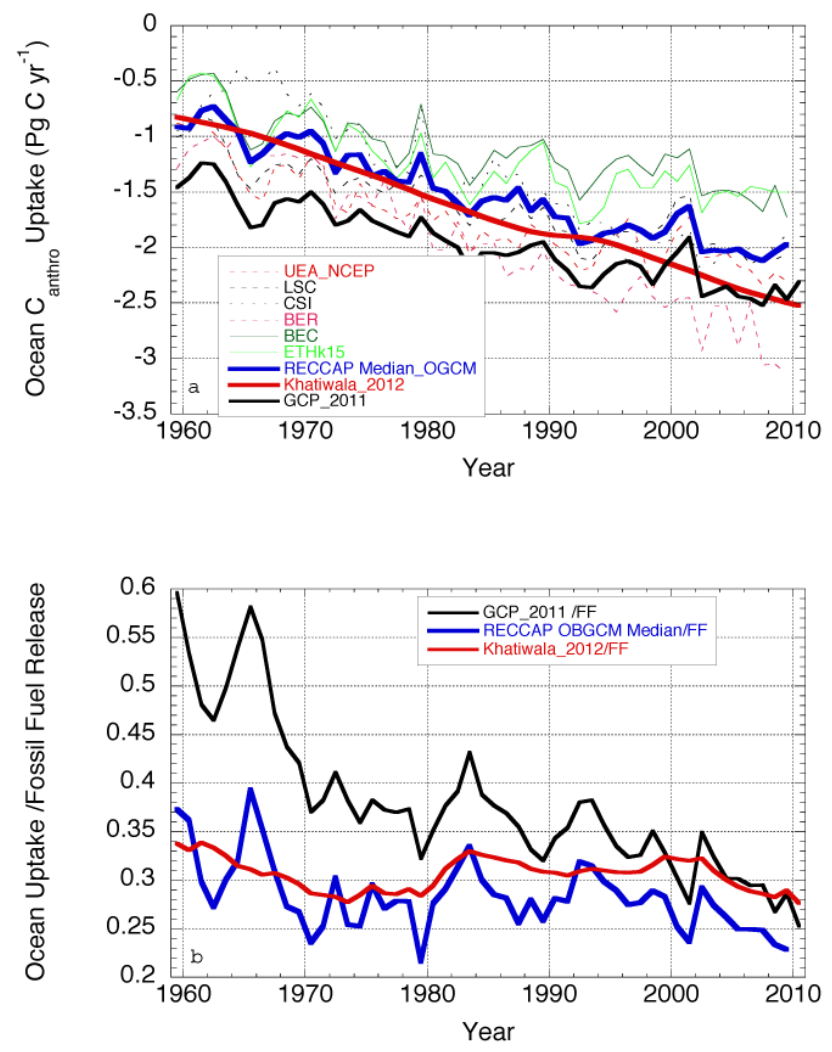

Fig. 3. (a) The $50 \mathrm{yr}$ globally integrated ocean anthropogenic $\mathrm{CO}_{2}$ uptake from OBGCMs used in RECCAP. The thin solid and dashed lines show the increasing annual uptake of the different models and their interannual variability (Tables 2 and 4). The thick solid blue line is the median of the OBGCMs; the thick solid red line is the output of the Green function method (Khatiwala et al., 2012) and the thick black line is the result from the GCP ocean model ensemble (http://www.globalcarbonproject.org/carbonbudget/index.htm). (b) The fraction of fossil fuel taken up by the ocean over the last $50 \mathrm{yr}$. The line colors refer to the model outputs as in (a).

\subsection{Factors influencing global ocean $\mathrm{CO}_{2}$ uptake estimates}

Long-term trends of ocean uptake of $\mathrm{CO}_{2}$ are limited to model outputs (e.g., Le Quéré et al., 2007; Sarmiento et al., 2010). Model derived estimates are regularly updated as part of the Global Carbon Project (GCP) (Le Quéré et al., 2009; www.globalcarbonproject.org/). The estimates consider mass balances and fluxes between ocean, atmosphere, and terrestrial biosphere to provide a consistent assessment. The annual estimates for the sea-air anthropogenic $\mathrm{CO}_{2}$ flux since 1960 from OBGCMs used in RECCAP is provided in Fig. 3. The median of anthropogenic $\mathrm{CO}_{2}$ uptake of six models increases from $0.8 \mathrm{Pg} \mathrm{Cyr}^{-1}$ in 1960 to $2 \mathrm{Pg} \mathrm{C} \mathrm{yr}^{-1}$ in 2010. A Green function approach relying heavily on ocean interior transient tracer distributions by Khatiwala et al. (2012) suggests a similar uptake as OBGCMs in 1960 but 
an appreciably greater uptake in 2010 . The results from the OBGCMs suggest that while the ocean sink has increased significantly over the past $50 \mathrm{yr}$, the increase is slower than the increase in fossil fuel $\mathrm{CO}_{2}$ emissions. Thus the percent of fossil fuel emissions absorbed by the oceans based on OBGCMs has steadily declined, while the Green function shows a much smaller relative decrease in uptake (Fig. 3b). The synthesis provided by the GCP shows the largest decrease in fractional uptake. It must be noted that these $50 \mathrm{yr}$ model runs lack of good information on physical forcing for the first half of the time series, which can impact the reliability of the results.

The $50 \mathrm{yr}$ record of sea-air $\mathrm{CO}_{2}$ fluxes provides an important benchmark but there are several shortcomings in the record, particularly as they pertain to forcing and variability. These issues are outlined below in a context of shorter and better constrained runs. The treatment of the different seaair $\mathrm{CO}_{2}$ flux components represent a substantial challenge when comparing flux estimates. The focus here is on the anthropogenic component of the $\mathrm{CO}_{2}$ flux, which we compute from estimates of the contemporary $\mathrm{CO}_{2}$ flux by subtracting the natural $\mathrm{CO}_{2}$ flux component. The latter is estimated by assuming that ocean circulation and biological activity has remained roughly constant on multidecadal scales over the last $250 \mathrm{yr}$. In this case, the natural $\mathrm{CO}_{2}$ flux, when integrated over the globe, cancels to zero except for the river-carbon induced outgassing flux of $\mathrm{CO}_{2}$. Although this assumption provides a good first estimate, the interannual variability, IAV and changes in circulation and biogeochemistry cause temporal fluctuations in the natural $\mathrm{CO}_{2}$ flux components. Moreover, there are no means of conclusively determining if the assumed centennial constancy in circulation and ocean biogeochemistry is correct. However, the steady levels of atmospheric $\mathrm{CO}_{2}$ in the millennia prior to the industrial revolution suggest that carbon cycling between ocean, atmosphere and terrestrial biosphere was in steady state. The deviations in natural $\mathrm{CO}_{2}$ fluxes between ocean and atmosphere are believed to occur on interannual timescales and variability in the decadal averages of the natural $\mathrm{CO}_{2}$ flux component in models is less than $\pm 0.3 \mathrm{Pg} \mathrm{Cyr}^{-1}$ (Lovenduski et al., 2008).

The contribution of the river-carbon induced outgassing flux to the natural sea-air flux of $\mathrm{CO}_{2}$ amounts to about $+0.45 \mathrm{Pg} \mathrm{C} \mathrm{yr}^{-1}$ (Jacobson et al., 2007). This needs to be accounted for when comparing model simulation of anthropogenic $\mathrm{CO}_{2}$ uptake with contemporary flux estimates based on $\Delta p \mathrm{CO}_{2}$ measurements. The river efflux is assumed to be relatively constant through time, so that a constant offset of $0.5 \mathrm{Pg} \mathrm{C} \mathrm{yr}^{-1}$ is applied to the sea-air $\mathrm{CO}_{2}$ fluxes based on $\Delta p \mathrm{CO}_{2}$ to obtain the anthropogenic $\mathrm{CO}_{2}$ uptake. Additional adjustments are applied to provide a uniform comparison of different estimates that include normalization of surface area of the ocean, sea ice, and coastal carbon input.

The observational benchmark for the net contemporary sea-air $\mathrm{CO}_{2}$ fluxes is the Takahashi et al. (2009) (T-09) $\Delta p \mathrm{CO}_{2}$ climatology. It is also the basis for our empirical approach to estimate interannual variability. However, even with over 3 million data points and its coarse resolution, the T-09 $p \mathrm{CO}_{2 \mathrm{w}}$ climatology is data limited. For much of the ocean, particularly the Southern Hemisphere, the seasonal cycle cannot be fully resolved from measurements alone. As shown in Fig. 2 only in the Northern Hemisphere are there sufficient monthly observations to create a full climatological year. A propagation of errors suggests an uncertainty in the global fluxes from the climatology of $50 \%$. However, the calculated sea-air fluxes are in better than $50 \%$ agreement with independent mass balance and model estimates (e.g., Gruber et al., 2009). The adjustments and breakdown of errors are listed in Table 1 along with an updated estimate that is described in the methods section.

The uncertainty estimates in Table 1 are described in section 6.4 of Takahashi et al. (2009). The breakdown of the uncertainty estimate shows that the smallest uncertainty in global sea-air $\mathrm{CO}_{2}$ fluxes is associated with the $\Delta p \mathrm{CO}_{2}$ estimate. This mirrors the conclusion for a regional estimate by Watson et al. (2009) that the decorrelation length scales on the order of hundreds of kilometers and the large number of measurements in each grid cell increase the certainty in $\triangle p \mathrm{CO}_{2}$ appreciably. However, the uncertainty estimate in $\triangle p \mathrm{CO}_{2}$ does not fully account for the dearth of measurements in many parts of the ocean. The uncertainty in the gas transfer velocity, $k$, is based on the range of common parameterizations presented in the literature. Recent syntheses suggest that globally the uncertainty in gas transfer is in the range of 10 to $20 \%$ (Ho et al., 2011), appreciably smaller than the uncertainty of $30 \%$ in Takahashi et al. (2009). Differences in global wind products are substantial, but this is partially compensated for by normalizing gas transfer-wind speed relationships such that they match in reconstructing the global ocean bomb- ${ }^{14} \mathrm{C}$ inventories (Sweeney et al., 2007; Naegler, 2009).

The largest uncertainty in the global $\mathrm{CO}_{2}$ flux climatology of T-09 is attributed to the assumption that the surface seawater $p \mathrm{CO}_{2}$ increases at the same rate as the atmospheric $\mathrm{CO}_{2}$ levels of $\approx 1.5 \mathrm{ppm} \mathrm{yr}^{-1}$ for the past four decades. The uncertainty estimate of $\pm 0.5 \mathrm{PgC} \mathrm{yr}^{-1}$ is derived from assuming an uncertainty of $\pm 0.5 \mu \mathrm{atm} \mathrm{yr}^{-1}$ in the oceanic $\mathrm{CO}_{2}$ increase and accounting for the data distribution in time. Therefore, the assumption that the $\Delta p \mathrm{CO}_{2}$ remains invariant is critical for the climatology. For regional shorter-term assessments, where data are not normalized to a common time reference, this uncertainty does not come into play.

The assumption of constant $\Delta p \mathrm{CO}_{2}$ over time is challenged by several observational and modeling efforts. McKinley et al. (2011) and Le Quéré et al. (2010) show that for several regions of the ocean the $\Delta p \mathrm{CO}_{2}$ does not remain constant over periods of up to three decades. This is attributed to circulation changes, and possibly changes in the biological cycle. The Southern Ocean (Le Quéré et al., 2007; Lovenduski et al., 2008; Lenton and Matear, 2007; Lenton et al., 2012) and eastern North Atlantic (Schuster et al., 2007; 
Table 1. Summary of different components of the globally integrated sea-air $\mathrm{CO}_{2}$ flux estimate including the sources and magnitude of the uncertainty.

\begin{tabular}{|c|c|c|c|c|c|}
\hline & \multicolumn{3}{|c|}{ Year 2000 from Takahashi et al. (2009) } & \multicolumn{2}{|c|}{ Updated estimate $^{\mathrm{a}}$} \\
\hline & $\mathrm{PgC} \mathrm{yr}^{-1}$ & $\%$ & ${\mathrm{PgC} \mathrm{yr}^{-1}}^{-1}$ & $\mathrm{PgC} \mathrm{yr}^{-1}$ & $\mathrm{PgC}_{\mathrm{yr}}{ }^{-1}$ \\
\hline Net flux & -1.38 & & & -1.18 & \\
\hline$\Delta p \mathrm{CO}_{2}$ & & $\pm 13 \%$ & \pm 0.18 & & \pm 0.18 \\
\hline$k$ & & $\pm 30 \%$ & \pm 0.42 & & \pm 0.2 \\
\hline Wind $(U)$ & & $\pm 20 \%$ & \pm 0.28 & & \pm 0.15 \\
\hline$<\mathrm{d}\left(p \mathrm{CO}_{2 \mathrm{w}}\right) \mathrm{d} t^{-1}>^{\mathrm{b}}$ & & $\pm 35 \%$ & \pm 0.5 & & \pm 0.5 \\
\hline Total & & $\pm 53 \%$ & \pm 0.7 & & \\
\hline Undersampling $^{\mathrm{c}}$ & -0.2 & & & -0.2 & \\
\hline Riverine carbon ${ }^{\mathrm{d}}$ & 0.4 & & \pm 0.2 & 0.45 & \pm 0.2 \\
\hline Coastal area & & & & -0.18 & \\
\hline Anthro $\mathrm{CO}_{2}$ flux & -2.0 & & $\pm 0.8^{\mathrm{e}}$ & -2.0 & \pm 0.6 \\
\hline
\end{tabular}

For a non-El Niño year 2000 (adapted from section 6, T-09). ${ }^{\text {a }}$ Details on the updated estimate are provided in the text.

${ }^{\mathrm{b}} \mathrm{d}\left(p \mathrm{CO}_{2 \mathrm{w}}\right) \mathrm{d} t^{-1}$ represents the error due to uncertainty in the mean rate of $p \mathrm{CO}_{2 \mathrm{w}}$ change of $\left(1.5 \pm 0.2 \mu \mathrm{atm} \mathrm{yr}^{-1}\right) \mathrm{used}^{\mathrm{c}}$ for correcting observed values measured in different years to the reference year $2000 .{ }^{c}$ The bias due to spatial undersampling is determined by using the temperature bias of $0.08^{\circ} \mathrm{C}$ between the measured SST used in the T- 09 climatology and a comprehensive global SST climatology. For an iso-chemical temperature dependence of $4.2 \%{ }^{\circ} \mathrm{C}^{-1}$ for $p \mathrm{CO}_{2 \mathrm{w}}$, this translates into a $p \mathrm{CO}_{2 \mathrm{w}}$ bias of $1.3 \mu \mathrm{atm}$ that in turn leads to a bias in globally integrated flux of $-0.2 \mathrm{Pg} \mathrm{C} \mathrm{yr}^{-1}$. That is, the ocean sink is greater when applying this correction. ${ }^{\mathrm{d}}$ The $\mathrm{CO}_{2}$ flux from riverine carbon input into the ocean is an efflux. To convert from the contemporary $\mathrm{CO}_{2}$ flux to the anthropogenic $\mathrm{CO}_{2}$ flux this value has to be subtracted. That is, the ocean anthropogenic $\mathrm{CO}_{2}$ uptake is greater than the net flux derived from the T-09 climatology. ${ }^{\mathrm{e}}$ Listed as $\pm 1.0 \mathrm{Pg} \mathrm{C} \mathrm{yr}^{-1}$ in $\mathrm{T}-09$.

Omar and Olsen, 2006; Metzl et al., 2010) show that $p \mathrm{CO}_{2 \mathrm{w}}$ has increased faster than atmospheric $\mathrm{CO}_{2}$, thereby decreasing the $\mathrm{CO}_{2}$ sink. In other areas such as the NW Atlantic (Park et al., 2012) and NW Pacific (Takahashi et al., 2006) $p \mathrm{CO}_{2 \mathrm{w}}$ is increasing at a slower rate the atmospheric increases.

In the Southern Ocean, where the changes are attributed to more upwelling of deep water, the changes are believed to be sustained. Increased upwelling is attributed to increases in zonal wind stress caused by large-scale reorganizations of the Southern Hemisphere climate system in response to global warming and stratospheric ozone loss (Thompson and Solomon, 2002). In other parts of the ocean, where the changes are attributed to more ephemeral causes, no systematic multidecadal changes in uptake are anticipated, as of yet, other than those caused by increasing atmospheric $\mathrm{CO}_{2} \mathrm{lev}$ els.

Winds have a major impact on sea-air $\mathrm{CO}_{2}$ fluxes through their influence on $k$ (Eq. 2). Long-term global wind records suggest an increase with time (Young et al., 2011). The global wind speed records are either based on atmospheric assimilations commonly used in weather forecasts, ship and buoy based observations, remotely sensed winds, or a combination thereof. Determining accurate trends is challenging because of changes in procedures and inputs. Assimilation models (e.g., NCEP (National Center for Environmental Prediction), ECMWF (European Centre for MediumRange Weather Forecasts)) are reanalyzed, often with as major objective to eliminate procedural biases. The reanalysis products show appreciable global and regional differ- ences in magnitude and variability (Wallcraft et al., 2009). For the RECCAP analysis the cross-calibrated multiplatform (CCMP) winds are used as they address many of the shortcomings of other products for the determination of sea-air $\mathrm{CO}_{2}$ fluxes.

\section{Methods}

Here we provide details on the bulk flux equation (Eq. 2) input parameters, which are key for surface ocean data-based methods and OBGCMs that provide fluxes based on $\Delta p \mathrm{CO}_{2}$. The updates to the input parameters used in Eq. (2) compared to $\mathrm{T}-09$ are emphasized. The procedure to determine a $20 \mathrm{yr}$ time record of fluxes from SST anomalies is provided. The OBGCMs, atmospheric and ocean inverse models, and estimates based on atmosphere $\mathrm{O}_{2} / \mathrm{N}_{2}$ are described briefly. The model analyses used here are referred to as Tier 1 methodologies in the RECCAP protocol (Canadell et al., 2011).

\subsection{Gas transfer velocities and wind speeds}

The estimate of the gas transfer velocity, $k$, is improved compared to previous assessments.

The global $\mathrm{CO}_{2}$ flux estimate reported in $\mathrm{T}-09$ used the NCEP-II assimilated wind speed product. In T-09, monthly mean winds were used for each $4^{\circ}$ by $5^{\circ}$ pixel and the variability around the mean was assumed to follow a Rayleigh distribution. The NCEP-II product is inconsistent in magnitude and wind speed pattern over the ocean compared to other products (Fig. 5) (Wallcraft et al., 2009). For the 


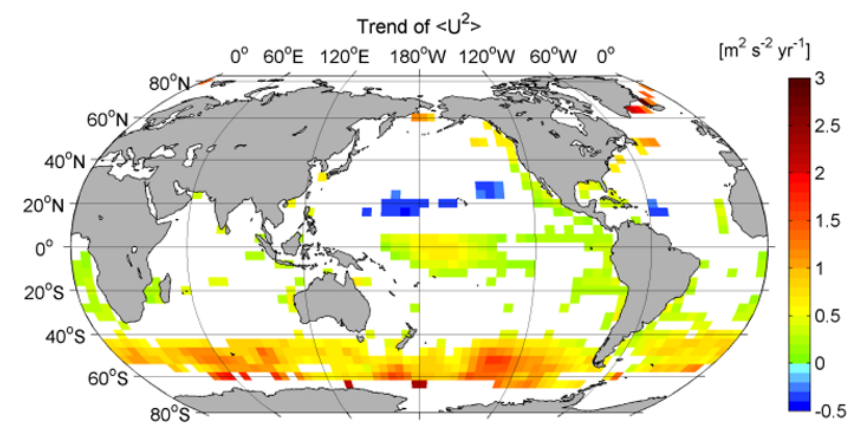

Fig. 4. Global pattern of the temporal trend of the second moment of surface wind speed $<U^{2}>$ for the $20 \mathrm{yr}$ CCMP wind product (1990-2009). Regions where trends are at less than $90 \%$ confidence level are masked.

observation-based estimate in RECCAP, the cross-calibrated multiplatform (CCMP) winds (Atlas et al., 2011) were chosen instead as the default product. The winds are provided at $6 \mathrm{~h}$ time intervals and $0.25^{\circ}$ resolution to determine the mean square wind speeds, or second moments, thereby accounting in a more robust way the actual variability of wind on gas transfer (Wanninkhof et al., 2009). The data are available at http://podaac.jpl.nasa.gov/DATA CATALOG/ccmpinfo.html.

The CCMP product is well documented and consistent for the entire time record. It covers the time period from 1 January 1990 to 31 December 2009, and shows appreciable trends in wind speed over time both regionally and globally. Figure 4 shows the decadal trends of the second moment of the winds, $\left\langle U^{2}>\right.$, used in the analyses (see Eq. 3). At $90 \%$ significance level the trends show decreases in $\left\langle U^{2}\right\rangle$ in the subtropical North Pacific and increases in the Southern Ocean and equatorial Pacific. The increasing winds have a direct effect on the sea-air $\mathrm{CO}_{2}$ flux through an impact on the gas transfer velocity but also an indirect effect on $\Delta p \mathrm{CO}_{2}$ from the wind impact on ocean circulation and mixed layer dynamics.

A procedure similar to Wanninkhof (1992) is used to determine the gas transfer-wind speed relationship. The gas transfer velocity is modeled as having a quadratic dependency with wind based on extensive wind tunnel and field studies. The magnitudes of gas transfer velocities determined from the second moments of the CCMP wind product are used in an inverse procedure to solve for the inventory of bomb ${ }^{14} \mathrm{C}$ in the ocean (Sweeney et al., 2007). The procedure optimizes for the coefficient of the gas transfer velocity, $a$ :

$a=k<U^{2}>^{-1}$,

where $k$ is the gas transfer velocity $\left(\mathrm{cm} \mathrm{h}^{-1}\right), "<>$ " denote temporal averages, and $<U^{2}>\left(\mathrm{m} \mathrm{s}^{-1}\right)^{2}$ is the time mean of the second moment of the wind speed at $10 \mathrm{~m}$ height. The coefficient, $a\left(\left(\mathrm{~cm} \mathrm{~h}^{-1}\right)\left(\mathrm{m} \mathrm{s}^{-1}\right)^{-2}\right)$, is adjusted such that the bomb $-{ }^{14} \mathrm{C}$ inventory increase in the ocean corresponds with

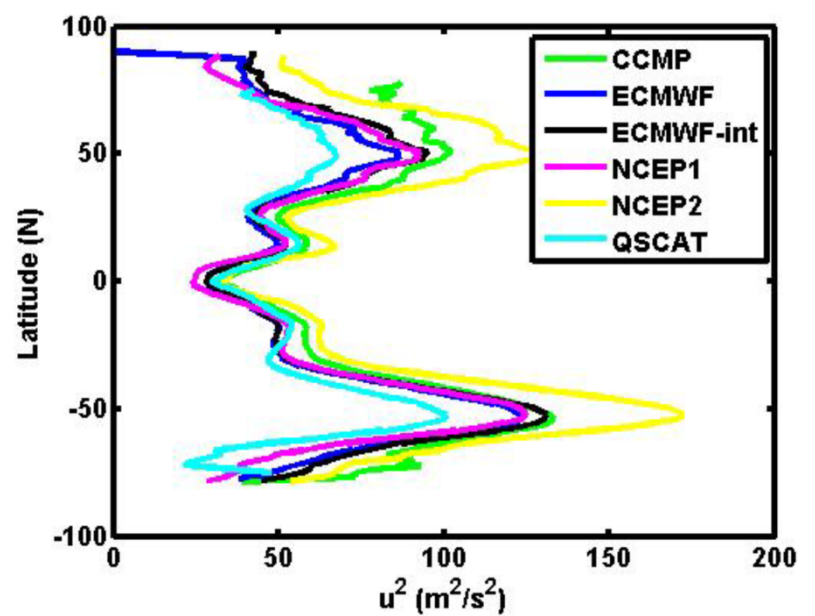

Fig. 5. Comparison of the zonal mean distribution of the second moment of ocean surface winds for the year 2000 for several global wind products. Differences of up to $30 \mathrm{~m}^{2} \mathrm{~s}^{-2}$ (wind speed difference $\approx 4 \mathrm{~m} \mathrm{~s}^{-1}$ ) are observed, and the biases are not always consistent between high and low latitudes. CCMP $=$ Cross Calibrated Multi-Platform winds (Atlas et al., 2011); ECWMF = European Center for Medium Weather Forecasting; NCEP = National Center for Environmental Prediction; QSCAT = QuikSCAT polar orbiting satellite with an $1800 \mathrm{~km}$ wide measurement swath on the earth's surface equipped with the microwave scatterometer SeaWinds.

the atmospheric ${ }^{14} \mathrm{C}$ history. In Sweeney et al. (2007) the NCEP-II winds were used to optimize $a$ while here the optimization was rerun for the CCMP winds thereby decreasing the uncertainty and bias in the flux using the CCMP wind product.

The optimal coefficient for the gas transfer velocity parameterization is 0.251 and:

$k=0.251(\mathrm{Sc} / 660)^{-0.5}<U^{2}>$,

where $\mathrm{Sc}$ is the Schmidt number of $\mathrm{CO}_{2}$ in seawater at a given SST. The relationship of Sc for $\mathrm{CO}_{2}$ with $\mathrm{SST}$ in seawater is: $\mathrm{Sc}=2073.1-$ $125.62 \times \mathrm{SST}+3.6276 \times \mathrm{SST}^{2}-0.043219 \times \mathrm{SST}^{3} \quad($ Wanninkhof, 1992). The parameterization in Eq. (4) shows agreement within $15 \%$ with the parameterizations derived from local gas exchange tracer studies (Ho et al., 2006, 2011; Nightingale et al., 2000), despite these studies using different wind products and gases other than $\mathrm{CO}_{2}$. Some local studies suggest that results can be better fitted with higher-order polynomials or other forcing functions (McNeil et al., 2009; Jackson et al., 2012). However, for the prevailing wind speeds ranging from $4-12 \mathrm{~m} \mathrm{~s}^{-1}$ a quadratic appears appropriate for global-scale analyses of $\mathrm{CO}_{2}$ fluxes (Wanninkhof et al., 2009). 


\subsection{The impact of the updated gas transfer velocity parameterization on global fluxes}

The CCMP wind product averaged over the $4^{\circ} \times 5^{\circ}$ grid yields a global average, $20 \mathrm{yr}$ mean, wind speed $<\mathrm{U}>$ of $7.6 \mathrm{~m} \mathrm{~s}^{-1}$ and a second moment, $\left\langle U^{2}>\right.$ of $69.1\left(\mathrm{~m} \mathrm{~s}^{-1}\right)^{2}$. Equation (4) yields a global average gas transfer velocity $<\mathrm{k}>$ of $15.95 \mathrm{~cm} \mathrm{~h}^{-1}$, and a global sea-air $\mathrm{CO}_{2}$ flux of $-1.18 \mathrm{Pg} \mathrm{Cyr}^{-1}$ when applied to the Takahashi $\Delta p \mathrm{CO}_{2}$ climatology (downloaded October 2010 from: http://www.ldeo.columbia.edu/res/pi/CO2/ carbondioxide/pages/air_sea_flux_2010.html). For comparison the net sea-air flux determined by T-09 using NCEP-II winds is $-1.38 \mathrm{Pg} \mathrm{Cyr}^{-1}$ (Table 1). The $15 \%$ difference indicates the sensitivity of global sea-air fluxes to wind speed product and wind speed parameterization.

\subsection{Method for estimating interannual variability (IAV) and decadal trends in $\Delta p \mathrm{CO}_{2}$ using a data-based approach}

There are limited observational data on global trends and variability in ocean sea-air $\mathrm{CO}_{2}$ fluxes. An empirical approach first presented in Lee et al. (1998) and improved in Park et al. (2010a), henceforth referred to as P-10, provides an assessment of IAV based on seasonal correlations of $p \mathrm{CO}_{2 \mathrm{w}}$ and SST that are used with the measured interannual SST variability. This approach is applied to the T-09 climatology as follows: The monthly mean sea-air $\mathrm{CO}_{2}$ flux for each $4^{\circ} \times 5^{\circ}$ grid cell for an individual year other than the climatological year 2000 is estimated from the global $p \mathrm{CO}_{2 \mathrm{w}}$ climatology, and $p \mathrm{CO}_{2 \mathrm{w}}$ anomalies determined from subannual $p \mathrm{CO}_{2 \mathrm{w}}-\mathrm{SST}$ relationships. Subannual timescales are defined as seasonal to up to a year. The subannual $p \mathrm{CO}_{2 \mathrm{w}}-\mathrm{SST}$ relationships are derived from one to four linear fits of $p \mathrm{CO}_{2 \mathrm{w}}$ and SST for each of the 1759 $4^{\circ} \times 5^{\circ}$ grid cells in the T- 09 climatology. The number of subannual segments chosen to delineate the subannual trends is kept to a minimum but sufficient to characterize the relationship between $p \mathrm{CO}_{2 \mathrm{w}}$ and SST for each location. Fewer unique segments decrease the uncertainty in the $p \mathrm{CO}_{2 \mathrm{w}}-$ SST relationships. The monthly $<U^{2}>$ is from the CCMP product, and the monthly mean SST is from the NOAA Optimum Interpolation (OI) SST product (Reynolds et al., 2007; http://www.cdc.noaa.gov/data/gridded/data.noaa.oisst. $\mathrm{v} 2 . \mathrm{html})$. Sea level pressures from NCEP-II for each grid cell are used to determine the $p \mathrm{CO}_{2 \mathrm{a}}$ from the measured $\mathrm{XCO}_{2 \mathrm{a}}$. Details are provided in Park et al. (2010b).

For the central and eastern equatorial Pacific $\left(6^{\circ} \mathrm{N}-10^{\circ} \mathrm{S}\right.$ and $80^{\circ} \mathrm{W}-165^{\circ} \mathrm{E}$ ) empirical $p \mathrm{CO}_{2 \mathrm{w}}-\mathrm{SST}$ equations are derived from a large quantity of multiyear observations that were collected from 1979 to 2008 (updated from Feely et al., 2006). Based on the observations over the last several decades it is clear that the drivers of IAV in this region are different from those of seasonal variability (Ishii et al., 2013).
The period of investigation covers seven El Niño and five La Nina periods. Unique $p \mathrm{CO}_{2 \mathrm{w}}-\mathrm{SST}$ equations for three different time periods (1979-1989, 1990-1998, and mid-19982008) that reflect the modulation of ENSO (El Niño/Southern Oscillation) by the Pacific Decadal Oscillation (PDO) are used. Using these relationships, the IAV based on the annual values for this region is $0.07 \mathrm{Pg} \mathrm{Cyr}^{-1}(1 \sigma)$ for the 1990 2009 time period.

The empirical method of P-10 to assess IAV is tied to the $\Delta p \mathrm{CO}_{2}$ climatology referenced to year 2000. Changes in biogeochemistry of surface seawater associated with SST changes will be reflected as long as the same mechanisms that relate subannual $p \mathrm{CO}_{2 \mathrm{w}}$ change to SST control the interannual $p \mathrm{CO}_{2 \mathrm{w}}-\mathrm{SST}$ relationships. A weak increasing trend in $p \mathrm{CO}_{2 \mathrm{w}}$, associated with surface ocean warming is estimated by the $\mathrm{P}-10$ method over the 20 -year period. This leads to a reduction in net global ocean $\mathrm{CO}_{2}$ uptake (see below).

The $\mathrm{P}-10$ method implicitly assumes that $p \mathrm{CO}_{2 \mathrm{w}}$ increases at the same rate as atmospheric $\mathrm{CO}_{2}$ levels, that is, the $\Delta p \mathrm{CO}_{2}$ remains constant on multiyear scales. It thus cannot reproduce trends tied to increasing atmospheric $\mathrm{CO}_{2}$ level. To account for varying regional interannual changes in $\triangle p \mathrm{CO}_{2}$ the " $\mathrm{CO}_{2}$-only" run of NCAR CCSM-3 model (National Center for Atmospheric Research's Community Climate System Model Version 3; Doney et al., 2009a, b) for the period of 1987-2006 is used. This model output is produced using a repeat annual cycle of physical forcing and rising atmospheric $\mathrm{CO}_{2}$. In each $4^{\circ} \times 5^{\circ}$ grid cell, the trend in modeled $p \mathrm{CO}_{2 \mathrm{w}}$ is computed by a linear regression with deseasonalized monthly values using a harmonic function. Approximately $75 \%$ of the grid cells have statistically significant positive or negative trends in $\Delta p \mathrm{CO}_{2}(p<0.05)$ over the past two decades. For the remaining $25 \%$ of the grid cells with no significant trends in $\Delta p \mathrm{CO}_{2}$, the $p \mathrm{CO}_{2 w}$ increases at the same rate as atmospheric $\mathrm{CO}_{2}$. From these trends the " $\mathrm{CO}_{2}$-only" fluxes are determined for each grid cell and they are added to $\mathrm{CO}_{2}$ fluxes from the empirical model to estimate the total contemporary sea-air $\mathrm{CO}_{2}$ flux from 1990 to 2009. Global maps of the trends of the $\mathrm{CO}_{2}$-only output, using a different model but with similar results, can be found in Fig. 4b of Le Quéré et al. (2010).

\subsection{Ocean global circulation models with biogeochemistry (OBGCMs)}

The trends and variability observed in the models are caused by changing physical forcing and the resulting changes in circulation and biogeochemistry. A list of the OBGCMs used in RECCAP, with a pertinent reference, is shown in Table 2. The model output and metadata of the models used in the discussion are provided at the RECCAP website (http: //www.globalcarbonproject.org/reccap/products.htm). Of the 9 model runs provided in RECCAP, several are from the same model but using different gas exchange or wind forcing. Only the LSC (Laboratoire des Sciences du Climat et 
de l'Environnement) and UEA (University of East Anglia) models include the input of riverine carbon but the input does not contribute to subsequent outgassing. Therefore, the flux estimates from all models provide the contemporary sea-air $\mathrm{CO}_{2}$ flux. However, since without riverine carbon outgassing the natural $\mathrm{CO}_{2}$ flux component is globally nearly balanced $(\approx 0)$, the contemporary flux in the OBGCMs used equals the sea-air anthropogenic $\mathrm{CO}_{2}$ flux.

\subsection{Other methods of determining global sea-air $\mathrm{CO}_{2}$ fluxes}

Several other global estimates that rely on changes in atmospheric or oceanic anthropogenic $\mathrm{CO}_{2}$ inventories are compared. These include results from eleven atmospheric inverse models provided by RECCAP, those relying on the atmospheric $\mathrm{O}_{2} / \mathrm{N}_{2}$ record, and ocean inventory changes using transient tracers based on a Green function analysis. Atmospheric inversions rely on the interpretation of atmospheric $\mathrm{CO}_{2}$ gradients, but given the under-constrained nature of this inversion, they need prior information for the sea-air $\mathrm{CO}_{2}$ fluxes. Sea-air $\mathrm{CO}_{2}$ flux climatologies such as that of T-09 are used as priors. As a result, these estimates are contemporary fluxes and include natural (with river outgassing) and anthropogenic $\mathrm{CO}_{2}$ fluxes. As they use the observed sea-air $\mathrm{CO}_{2}$ flux as a prior they are not a truly independent estimate of sea-air $\mathrm{CO}_{2}$ fluxes. In contrast, the atmospheric $\mathrm{O}_{2} / \mathrm{N}_{2}$ approach provides a strong independent constraint for the anthropogenic $\mathrm{CO}_{2}$ flux component only. Estimates based on $\mathrm{O}_{2} / \mathrm{N}_{2}$ trends in the atmosphere from 1989-2003 can be found in Manning and Keeling (2006), while results from 2000-2010 are presented in Ishidoya et al. (2012).

The anthropogenic $\mathrm{CO}_{2}$ uptake inferred from changing oceanic inventories is further detailed in Khatiwala et al. (2012). Briefly, the inventory-based estimates include an empirical Green function approach (Khatiwala et al., 2009, 2012) and ocean inversion model-based approaches, which are synthesized in the ocean inversion project (OIP) (Mikaloff Fletcher et al., 2006; Gruber et al., 2009). These approaches are based on the assumption of a steady-state ocean circulation and biogeochemistry and, therefore, only resolve the smoothly evolving changes in the oceanic uptake of anthropogenic $\mathrm{CO}_{2}$ driven by the increase in atmospheric $\mathrm{CO}_{2}$. That is, they do not resolve interannual and subannual variability.

\section{Discussion}

\subsection{Global sea-air $\mathrm{CO}_{2}$ fluxes}

A tabular summary of the decadal mean anthropogenic $\mathrm{CO}_{2}$ uptake centered on the year 2000, based on observations and the median value of different types of models, is provided in Table 3. The IAV, SAV and trends of the contemporary seaair $\mathrm{CO}_{2}$ flux are shown in Table 3 as well. The IAV and SAV are dominated by the natural $\mathrm{CO}_{2}$ flux. The trend from 19902009 is primarily caused by the anthropogenic component with modulation by the natural cycle.

The empirical estimates of sea-air fluxes follow the procedures and assumptions of T-09 and P-10 with the adaptations described in Sect. 3. The fluxes are extrapolated to include the coastal regions by scaling to the increased surface area assuming that the fluxes in the coastal regions are the same as for the adjacent region used in the OIP. Fluxes in the coastal area are highly variable but net fluxes on the whole appear similar to that of adjacent ocean areas, with some regional exceptions. Eastern upwelling zones show large effluxes near the coast, and riverine dominated shelves show influxes (Borges et al., 2005; Chavez et al., 2007; Liu et al., 2010; Cai, 2011). Incorporating the coastal fluxes based solely on area increases the influx by $-0.18 \mathrm{PgC} \mathrm{yr}^{-1}$. A global synthesis of ocean-margin carbon uptake estimates a flux of $-0.29 \mathrm{Pg} \mathrm{C} \mathrm{yr}^{-1}$ (Jahnke, 2010), but the shelf area in this estimate is twice that of the areal adjustment applied here.

The differences in assumptions compared to those used in T-09 lead to a $0.19 \mathrm{Pg} \mathrm{C} \mathrm{yr}^{-1}$ smaller open ocean contemporary $\mathrm{CO}_{2}$ uptake (Table 1). Several adjustments are made to the contemporary flux to obtain a global anthropogenic flux. These adjustments yield an anthropogenic $\mathrm{CO}_{2}$ flux of $-2.0 \mathrm{PgC} \mathrm{yr}^{-1}$ that is the same as the $-2.0 \mathrm{PgC} \mathrm{yr}^{-1}$ estimate presented in T-09. As shown in Table 1, the lower contemporary uptake in the open ocean is compensated for by including the influx in coastal areas of $-0.18 \mathrm{PgC}^{-1}$ in our flux determination. Our estimate has an uncertainty of $0.6 \mathrm{Pg} \mathrm{Cyr}^{-1}$ compared to $0.8 \mathrm{PgC} \mathrm{yr}^{-1}$ in $\mathrm{T}-09$. This is largely due the reduced uncertainty in the determination of gas transfer velocities and winds.

Models and atmospheric observing approaches generally report smaller uncertainties than those based on surface $\mathrm{CO}_{2}$ levels and bulk flux approaches. The uncertainties in models are determined in a different fashion and generally expressed in terms of a deviation from multimodel ensemble comparisons. An important consideration when determining uncertainty in this fashion is that model architecture and forcing are often similar, which can lead to an unrealistic good correspondence between them. Graphical summaries of the seaair anthropogenic $\mathrm{CO}_{2}$ fluxes for the OBGCMs and ocean inverse estimates, and the atmospheric inversions from 1990 to 2009 are presented in Figs. 6 and 7, respectively. A summary of the medians of different methods is shown in Fig. 8.

Ocean inversions rely on inorganic carbon measurements in the ocean interior and can only provide an average sea-air anthropogenic $\mathrm{CO}_{2}$ flux based on cumulative anthropogenic $\mathrm{CO}_{2}$ uptake since the preindustrial era. A comprehensive ocean inversion estimate of $\mathrm{CO}_{2}$ uptake based on a suite of ten general ocean circulation models as part of the OIP is presented in Gruber et al. (2009). This inversion-based estimate has a reported uncertainty of $\pm 0.3 \mathrm{PgC} \mathrm{yr}^{-1}$, determined from the spread of model results. The uncertainties 
Table 2. Ocean general circulation models with biogeochemistry (OBGCMs) ${ }^{\mathrm{a}}$.

\begin{tabular}{|c|c|c|c|}
\hline Abbreviation & Name & Key Reference & Years used \\
\hline BER & MICOM-HAMOCCv1 & Assmann et al. (2010) & 1990 to 2009 \\
\hline CSI & CSIRO-BOBGCM & Matear and Lenton (2008) & 1990 to 2009 \\
\hline BEC & CCSM-BEC & Doney et al. (2009a, b) & 1990 to 2009 \\
\hline $\mathrm{ETH}_{\mathrm{k} 15}^{\mathrm{b}}$ & $\mathrm{CCSM}_{-} \mathrm{ETH}_{\mathrm{k} 15}$ & Graven et al. (2012) & 1990 to 2007 \\
\hline $\mathrm{ETH}_{\mathrm{k} 19}^{\mathrm{c}}$ & CCSM-ETH $_{\mathrm{k} 19}$ & - & 1990 to 2007 \\
\hline $\operatorname{LSC}^{\mathrm{K} 19}$ & NEMO-PISCES & Aumont and Bopp (2006) & 1990 to 2009 \\
\hline $\mathrm{UEA}_{\mathrm{NCEP}}^{\mathrm{d}}$ & NEMO-PlankTOM5 $5_{\text {NCEP }}$ & Buitenhuis et al. (2010) & 1990 to 2009 \\
\hline $\mathrm{UEA}_{\mathrm{ECMWF}}^{\mathrm{e}}$ & NEMO-PlankTOM5 $5_{\text {ECMWF }}$ & - & 1990 to 2009 \\
\hline $\mathrm{UEA}_{\mathrm{CCMP}}^{\mathrm{f}}$ & NEMO-PlankTOM5 ${ }_{\text {CCMP }}$ & - & 1990 to 2009 \\
\hline
\end{tabular}

a Further details on models are provided in the key reference and the RECCAP website:

http://www.globalcarbonproject.org/reccap/products.htm. ${ }^{\mathrm{b}} \mathrm{ETH}_{\mathrm{k} 15}$ : CCSM-ETH model with a prescribed global average gas transfer velocity of $15 \mathrm{~cm} \mathrm{~h}^{-1} .{ }^{\mathrm{c}} \mathrm{ETH}_{\mathrm{k} 19}$ : CCSM-ETH model with a prescribed global average gas transfer velocity of $19 \mathrm{~cm} \mathrm{~h}^{-1}$. ${ }^{\mathrm{d}}$ UEA $_{\text {NCEP }}$ : NEMO-PlankTOM5 model with NCEP core forcing. ${ }^{\text {e }}$ UEAECMWF $_{\text {NEMO-PlankTOM5 }}$

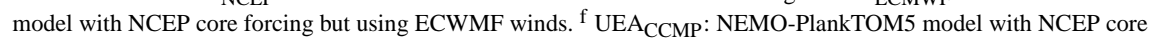
forcing but using CCMP winds.

Table 3. Median sea-air anthropogenic $\mathrm{CO}_{2}$ fluxes for the different approaches centered on year 2000.

\begin{tabular}{lrrrrr}
\hline Approach & Anthr. $\mathrm{CO}_{2}$ flux & Uncertainty & $\mathrm{IAV}^{\mathrm{e}}$ & $\mathrm{SAV}^{\mathrm{f}}$ & Trend \\
\hline & $\mathrm{Pg} \mathrm{C} \mathrm{yr}^{-1}$ & $\mathrm{Pg} \mathrm{C} \mathrm{yr}^{-1}$ & $\mathrm{Pg} \mathrm{C} \mathrm{yr}^{-1}$ & $\begin{array}{r}\left(\mathrm{Pg} \mathrm{C} \mathrm{yr}^{-1}\right) \\
\text { decade }^{-1}\end{array}$ \\
\hline Empirical & & & & & -0.15 \\
OBGCM & -2.0 & $\pm 0.6^{\mathrm{a}}$ & 0.20 & 0.61 & -0.14 \\
Atm. Inversion & -1.9 & $\pm 0.3^{\mathrm{b}}$ & 0.16 & 0.38 & -0.13 \\
Ocean Inversion & -2.1 & $\pm 0.3^{\mathrm{c}}$ & 0.40 & 0.41 & $-0.5^{j}$ \\
Interior (Green function) $\mathrm{g}$ & -2.4 & $\pm 0.3^{\mathrm{d}}$ & & & -0.35 \\
$\mathrm{O}_{2} / \mathrm{N}_{2}^{\mathrm{h}}$ & -2.2 & \pm 0.5 & - & - & \\
$\mathrm{O}_{2} / \mathrm{N}_{2}^{1}$ & -2.2 & \pm 0.6 & & & \\
\hline
\end{tabular}

a Root mean square of uncertainty in different components of the flux (see Table 1). ${ }^{\mathrm{b}}$ Median absolute deviation of the six model outputs used to determine the median (for 6 model outputs: LSC, UEA $\mathrm{NCEP}, \mathrm{CSI}, \mathrm{BER}, \mathrm{BEC}$ and $\mathrm{ETH}_{\mathrm{k} 15}$ ). ${ }^{\mathrm{c}}$ Median absolute deviation of eleven model outputs used to determine the median. ${ }^{\mathrm{d}}$ Median absolute deviation of the ten model outputs used to determine the median. ${ }^{e}$ Interannual variability (IAV) for the median values for the 6 models listed in b. ${ }^{f}$ Subannual variability (SAV) for the median values (for 5 model outputs: LSC, UEA NCEP, CSI, BEC and ETH $\mathrm{K}_{\mathrm{k} 15}$ ). ${ }^{\mathrm{g}}$ Based on interior ocean changes using transient tracers and a Green function (Khatiwala et al., 2009, 2012). ${ }^{\mathrm{h}}$ For 1993-2003 (Manning and Keeling, 2006). ${ }^{\mathrm{i}}$ For 2000-2010 (Ishidoya et al., 2012). ${ }^{\mathrm{j}}$ Calculated assuming steady ocean circulation and $\mathrm{CO}_{2}$ uptake proportional to atmospheric $\mathrm{CO}_{2}$ increases.

in ocean inversions include the partitioning of anthropogenic from natural dissolved inorganic carbon. The largest uncertainty lies in ocean transport and mixing. The average anthropogenic $\mathrm{CO}_{2}$ uptake by the inversions provided in RECCAP is an update of the OIP (Mikaloff Fletcher et al., 2006; Gruber et al., 2009) with results shown in Fig. 6. The reported values for 1994 were scaled by a factor of 1.109 and 1.23 for the years 2000 and 2005, respectively, based on the scaling used in the inversion procedure itself (Mikaloff Fletcher et al., 2006). The globally integrated seaair anthropogenic $\mathrm{CO}_{2}$ fluxes, nominally, for 1995, 2000 and 2005 are $-2.18 \pm 0.25,-2.42 \pm 0.28$, and $-2.68 \pm 0.31$ ( $1 \sigma) \mathrm{Pg} \mathrm{C} \mathrm{yr}^{-1}$, respectively.

Jacobson et al. (2007) present a comprehensive joint ocean-atmosphere inversion scheme applying both atmo- spheric inverse and oceanic inverse constraints that include sea-air $\mathrm{CO}_{2}$ flux estimates modified from Takahashi et al. (2002). The resulting contemporary sea-air fluxes are heavily weighted towards the (interior) oceanic inverse due to the large number of interior data points and sluggish ocean circulation/transport compared to the atmosphere. It yields results of an anthropogenic flux of $-2.1 \mathrm{Pg} \mathrm{C} \mathrm{yr}^{-1}$ for the time period from 1992-1996 with an uncertainty of $\pm 0.2 \mathrm{Pg} \mathrm{Cyr}^{-1}$, which is similar to the value of $-2.18 \mathrm{Pg} \mathrm{C} \mathrm{yr}^{-1}$ of Gruber et al. (2009). The uncertainty is lower than that of Gruber et al. (2009) primarily because Jacobson et al. (2007) use a smaller number of general circulation models in their analyses.

Ocean inversions provide a well constrained ocean uptake of anthropogenic $\mathrm{CO}_{2}$ on multiyear timescales, but estimates 
Table 4. Comparison of sea-air anthropogenic $\mathrm{CO}_{2}$ flux, interannual and subannual variability of individual OBGCM outputs used.

\begin{tabular}{|c|c|c|c|c|}
\hline OBGCMs & Provided flux ${ }^{a}$ & $\mathrm{IAV}^{\mathrm{b}}$ & $\mathrm{SAV}^{\mathrm{c}}$ & Trend \\
\hline & $\mathrm{PgCyr}^{-1}$ & $\mathrm{PgCyr}^{-1}$ & $\mathrm{PgCyr}^{-1}$ & $\begin{array}{r}\left(\mathrm{Pg} \mathrm{C} \mathrm{yr}^{-1}\right) \\
\text { decade }^{-1}\end{array}$ \\
\hline NEMO-PlankTOM $5_{\mathrm{NCEP}}$ & -2.08 & 0.20 & 0.32 & -0.12 \\
\hline NEMO-PISCES & -1.93 & 0.22 & 0.32 & -0.08 \\
\hline CSIRO-OBGCM & -1.93 & 0.21 & 0.51 & -0.19 \\
\hline CCSM-BEC & -1.39 & 0.20 & 0.62 & -0.17 \\
\hline CCSM-ETHk $15^{\mathrm{d}}$ & -1.49 & 0.22 & 0.74 & 0.04 \\
\hline MICOM-HAMOCCv1 & -2.58 & 0.45 & 3.32 & -0.37 \\
\hline CCSM-ETHk19 ${ }^{d}$ & -1.53 & 0.24 & 0.87 & 0.07 \\
\hline NEMO-PlankTOM $5_{E C M W F}$ & -2.48 & 0.26 & 0.50 & -0.24 \\
\hline NEMO-PlankTOM5 ${ }_{\text {CCMP }}$ & -2.16 & 0.25 & 0.32 & -0.05 \\
\hline
\end{tabular}

${ }^{a}$ This analysis is performed without the adjustment to a common ocean surface area (Supplement A). ${ }^{b}$ IAV of median values: 0.16 (for 6 models: LSC, UEA $\mathrm{NCEP}, \mathrm{CSI}, \mathrm{BER}, \mathrm{BEC}$ and $\mathrm{ETH}_{\mathrm{k} 15}$ ). The italicized models are excluded from the calculation of IAV and SAV in Table $3 .{ }^{\mathrm{c}} \mathrm{SAV}$ of median values: 0.38 (for 5 models: LSC, UEA $\mathrm{NCEP}$, CSI, BEC and $\mathrm{ETH}_{\mathrm{k} 15}$ ). In addition to the italicized models, the MICOM-HAMOCCv1 is excluded from the summary of OBGCMs in Table 3 as it shows extremely high SAV due to known model deficiencies. ${ }^{d}$ For the period of 1990-2007.

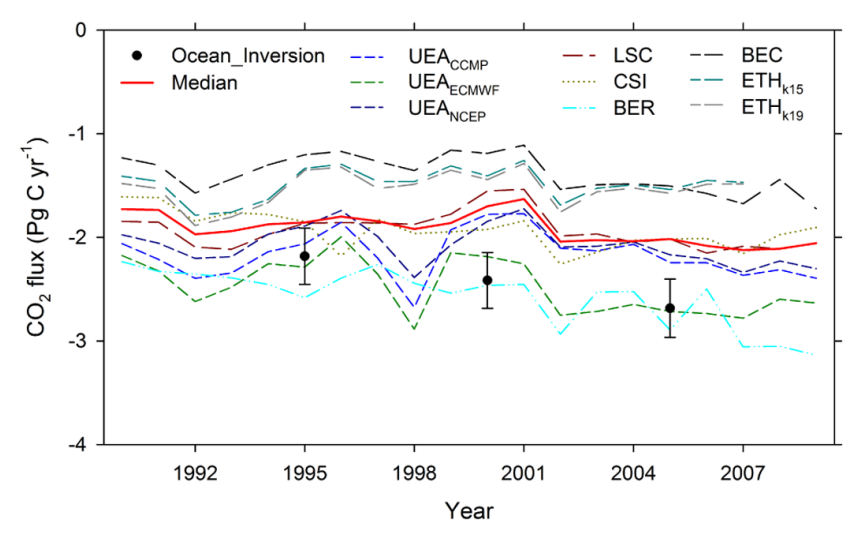

Fig. 6. The $20 \mathrm{yr}$ record of annual globally integrated sea-air $\mathrm{CO}_{2}$ fluxes from the ocean general circulation models, OBGCMs (dashed lines), and ocean inversion estimates (circles with uncertainty bars). Similar line types for the OBGCMs indicate that the models have the same heritage. The median (solid red line) is the

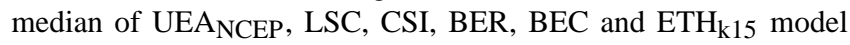
outputs.

at higher temporal resolution rely on ocean general circulation models with biogeochemistry (OBGCMs). A comprehensive synthesis of model performance on a previous generation OBGCMs was provided as part of the OCMIP (Ocean Carbon-Cycle Model Intercomparison Project) in the early 2000s (see e.g., Doney et al., 2004; Matsumoto et al., 2004). A more recent subset of models was used to determine the ocean sink for 1959-2008 (Le Quéré et al., 2009; Sarmiento et al., 2010). Initialization, forcing and biological representation for the model output used here differ for the models as summarized in the metadata on the RECCAP website and references in Table 2 . The models were run in hindcast mode,

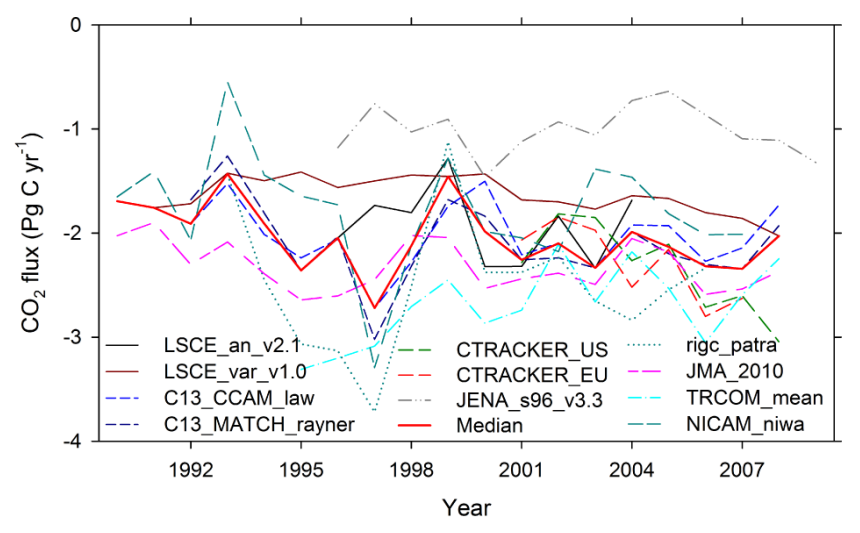

Fig. 7. The $20 \mathrm{yr}$ record of annual globally integrated sea-air $\mathrm{CO}_{2}$ fluxes from atmospheric inverse models. The red line is the median of all the inverse models shown.

i.e., they were driven by atmospheric forcing assimilation products such as NCEP or ECWMF, and with a prescribed atmospheric $\mathrm{CO}_{2}$ concentration using an observation based product such as GLOBALVIEW-CO 2 (2011).

Two things stand out in the $20 \mathrm{yr}$ time series of annual seaair $\mathrm{CO}_{2}$ fluxes from OBGCMs (Fig. 6). The models with a heritage traceable to the NCAR community ocean circulation model with biogeochemistry $\left(\mathrm{BEC}, \mathrm{ETH}_{\mathrm{k} 15}\right.$, and $\left.\mathrm{ETH}_{\mathrm{k} 19}\right)$ show about $0.5{\mathrm{PgC} \mathrm{yr}^{-1}}^{-1}$ less uptake than the others (Table 4). The UEA models are adjusted to an estimate of ocean uptake in the 1990s and therefore show a mean of anthropogenic $\mathrm{CO}_{2}$ uptake close to this estimate of $-2.2 \mathrm{Pg} \mathrm{C} \mathrm{yr}^{-1}$. The second significant difference in OBGCMs is their response to major climate reorganizations. The 1997/98 El Niño was one of the largest on record (see e.g., http://www. esrl.noaa.gov/psd/enso/mei/) with an expected net increase 


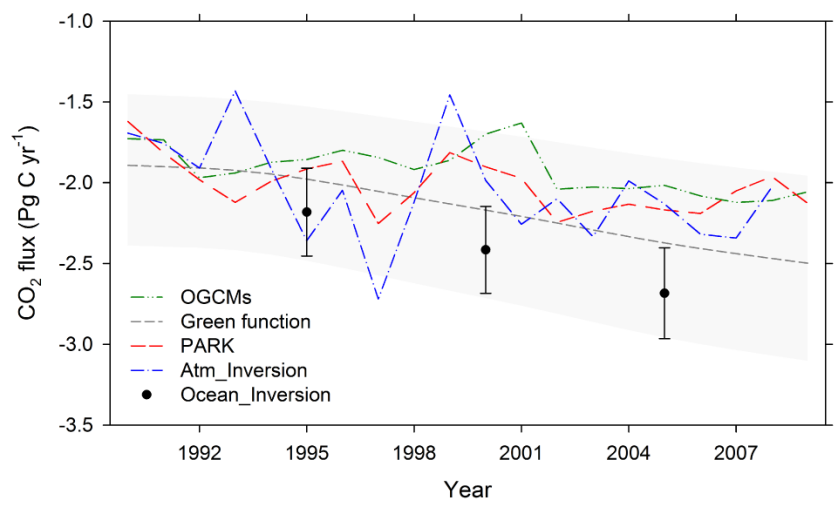

Fig. 8. The $20 \mathrm{yr}$ record of annual globally integrated sea-air $\mathrm{CO}_{2}$ fluxes for the different modeling approaches. For the OBGCMs and atmospheric inverses, the lines are plotted through the annual median values.

in ocean uptake due to reduced outgassing of $\mathrm{CO}_{2}$ in the equatorial Pacific (Feely et al., 2006). The models show greatly varying responses in phasing, magnitude and duration of $\mathrm{CO}_{2}$ flux anomalies (Fig. 6). The CCSM models show a peak-to-peak change of $0.2 \mathrm{PgC} \mathrm{yr}^{-1}$, while the NEMO (Nucleus for European Models of the Ocean) models show peak-to-peak changes of up to $1.0 \mathrm{Pg} \mathrm{C} \mathrm{yr}^{-1}$. The MICOMHAMOCCv1 (Miami Isopycnic Coordinate Ocean ModelHamburg Ocean Carbon Cycle version 1) model shows no global response to the El Niño, while the CSIRO (Commonwealth Scientific and Industrial Research Organisation) shows an increase in uptake over several years. The P-10 record shows an anomaly of about $0.3 \mathrm{PgC} \mathrm{yr}^{-1}$ with a recovery in less than $2 \mathrm{yr}$ (Figs. 8 and 10d).

For the estimate of the median anthropogenic $\mathrm{CO}_{2}$ uptake of the OBGCMs, we excluded model outputs that were largely similar and only differed in their forcing and, therefor, showed very similar results (Fig. 6). That is, only one of the three UEA model outputs (UEA $A_{\mathrm{NCEP}}$ ) and one of the two ETH (Swiss Federal Institute of Technology Zurich) $\left(\mathrm{ETH}_{\mathrm{k} 15}\right)$ model outputs were used. The solid red line in

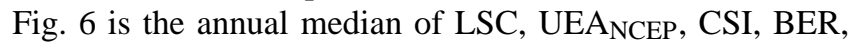
$\mathrm{BEC}$ and $\mathrm{ETH}_{\mathrm{k} 15}$ runs. The IAV of the median estimate of $0.16(1 \sigma) \mathrm{Pg} \mathrm{Cyr}^{-1}$ is damped compared to the mean IAV of the individual models of $0.25(1 \sigma) \mathrm{Pg} \mathrm{C} \mathrm{yr}^{-1}$, indicating that the variability in the individual models is not coherent. The median trend in anthropogenic $\mathrm{CO}_{2}$ uptake of the 6 models is $-0.14 \pm 0.02 \mathrm{PgC} \mathrm{yr}^{-1}$ decade $^{-1}(p<0.01)$. The median trend agrees with the trends of the individual models, that span the entire time period, indicating that each behaves similarly to the increase in atmospheric $\mathrm{CO}_{2}$.

Ocean anthropogenic $\mathrm{CO}_{2}$ uptake determined from atmospheric inverse models has a median value of $-2.1 \mathrm{Pg} \mathrm{C} \mathrm{yr}^{-1}$ (Table 3). The range and median of the uptake is similar to that of the OBGCMs (Fig. 8). The flux for atmospheric inverse models is $0.3 \mathrm{Pg} \mathrm{Cyr}^{-1}$ less than that of the ocean inversion model. The IAV is considerably greater at $0.40 \mathrm{Pg} \mathrm{Cyr}^{-1}(1 \sigma)$, based on the detrended median values of deseasonalized monthly anomalies (Table 3 ).

As with the OBGCMs, the response of the fluxes from the atmospheric inversions to the $1998 \mathrm{El}$ Niño varies appreciably from no impact to about $1.0 \mathrm{Pg} \mathrm{Cyr}^{-1}$. However, the atmospheric inversions that give a response show the maximum ocean uptake a year earlier (1997). The atmospheric inversions separate the seasonal and interannual $\mathrm{CO}_{2}$ flux of the ocean from that of the terrestrial biosphere that shows subannual variability in $\mathrm{CO}_{2}$ exchange that is an order of magnitude greater. Therefore, the uncertainty of the separation between ocean and terrestrial carbon fluxes dictates the variability in the adjacent oceans. The time-averaged globally integrated anthropogenic $\mathrm{CO}_{2}$ flux into the oceans from the atmospheric inversions is not independent from databased estimates since the $\Delta p \mathrm{CO}_{2}$ fields used in the $\mathrm{CO}_{2}$ flux climatology are used as a prior within the inversion. No estimate of the decadal trend is provided, as the atmospheric inversion runs from which the median estimate is determined differ in time span and time period.

\subsection{Trends and variability in wind, $\Delta p \mathrm{CO}_{2}$ and fluxes}

The trends and variability in fluxes as determined from the bulk flux equation (Eq. 2) are driven by changes in wind and $\Delta p \mathrm{CO}_{2}$. They are discussed in the context of the empirical approach in P-10. The impact of changing winds is different than that of OBGCMs as OBGCMs are dynamic in nature and higher winds in models will not only change the rate of gas exchange, but also the $\Delta p \mathrm{CO}_{2}$ field. For instance, higher winds in OBGCMs can result in decreased net flux into the ocean through enhanced upwelling of remineralized $\mathrm{CO}_{2}(\mathrm{Le}$ Quéré et al., 2007; Lovenduski et al., 2008). In contrast, applying higher winds to a static $\Delta p \mathrm{CO}_{2}$ field such as the T-09 climatology will result in increased $\mathrm{CO}_{2}$ uptake.

Detection of trends and IAV in $\mathrm{CO}_{2}$ fluxes is challenging due to large subannual (seasonal) changes in $\Delta p \mathrm{CO}_{2}$ and wind on regional scales. Thus, the quantification of these signals requires a long time series of measurements. Moreover, variability will differ for different ocean regions as detailed in the discussions of individual basins (Ishii et al., 2013; Lenton et al., 2013; Schuster et al., 2013). Here we provide a global zonal analysis of mean and spatiotemporal variability for the global ocean of wind, $\Delta p \mathrm{CO}_{2}$, and the sea-air $\mathrm{CO}_{2}$ flux density, i.e., the flux per unit area. Figure 9 shows the $20 \mathrm{yr}$ zonal mean and standard deviation of zonal mean for $<U^{2}>0.5$ and flux density (in mol m${ }^{-2}$ month $^{-1}$ ), along with the climatological annual zonal mean and standard deviation of the monthly $\Delta p \mathrm{CO}_{2}$ climatology. The $<U^{2}>0.5$ show low winds in the tropics and steady increases towards higher southern and northern latitudes with relatively constant values in the subtropical high-pressure regions around $30^{\circ} \mathrm{N}$ and $30^{\circ} \mathrm{S}$. The Southern Ocean experiences higher $<U^{2}>^{0.5}$ than the northern oceans $\left(11 \mathrm{~m} \mathrm{~s}^{-1}\right.$ vs. $\left.10 \mathrm{~m} \mathrm{~s}^{-1}\right)$. 
At latitudes greater than $60^{\circ}$ wind speeds decrease slightly. The variance pattern of winds, expressed as the standard deviation from the $20 \mathrm{yr}$ mean in Figure 9a, differs between the northern and southern hemisphere. There is more variability in winds in the mid- to high-latitudes $\left(>30^{\circ}\right)$ in the Northern Hemisphere than in the Southern Hemisphere. Variability is at a minimum in the high-pressure regimes in the subtropics, and at the equator.

The annual mean $\Delta p \mathrm{CO}_{2}$ from the $\mathrm{T}-09$ climatology (Fig. 9b) shows maximum values just south of the equator and a decline to the north and south. The $\Delta p \mathrm{CO}_{2}$ equals approximately 0 near $18-20^{\circ}$ and reaches a minimum of -20 to $-25 \mu \mathrm{atm}$ at $40^{\circ}$ for both hemispheres. At high northern latitudes the average $\Delta p \mathrm{CO}_{2}$ continues to drop precipitously while in the Southern Hemisphere it increases and, on climatological annual average, becomes slightly positive near the Antarctic ice edge causing a net $\mathrm{CO}_{2}$ flux to the atmosphere (Lenton et al., 2013). The variance in $\Delta p \mathrm{CO}_{2}$ in the Northern Hemisphere is appreciably greater than in the Southern Hemisphere, as is the case with the wind speed.

The flux density, computed from a $20 \mathrm{yr}$ wind speed record and the climatological $p \mathrm{CO}_{2}$, mirrors the trends in $\Delta p \mathrm{CO}_{2}$ but with amplification at mid-latitudes due to higher winds. The largest sink per unit area is in the Northern Hemisphere, but the substantially larger surface area in the Southern Hemisphere causes a much greater spatially integrated mass exchange (see Table 6 in T-09). Because the variance in wind speed and $\Delta p \mathrm{CO}_{2}$ have the same pattern, the flux density at mid- to high-latitudes in the Northern Hemisphere show twice the SAV compared to the Southern Hemisphere.

The greater $\mathrm{SAV}$ in $\mathrm{CO}_{2}$ flux in the Northern Hemisphere compared to the Southern Hemisphere is likely because of the significantly greater landmasses in the north. The landocean contrast, along with continental input and bathymetry, causes greater variability in weather systems, (micro) nutrient input and seasonal temperature variations in the North, all which contribute to higher variability in sea-air $\mathrm{CO}_{2}$ flux density.

Supplement B (Fig. B1b) shows a global map of SAV. Regions with high variability include the upwelling region in the Arabian Sea caused by the high winds in the summer monsoon. High variability from the annual mean of the seaair $\mathrm{CO}_{2}$ fluxes are also found in the eastern tropical South Pacific, attributed to variations in upwelling along the western boundary. In the southwestern Atlantic, near the Malvinas confluence area, SAV in fluxes is caused by variation in currents, shallow bathymetry and associated plankton blooms. Low SAV is seen in the subtropical and subpolar region of the southeast Pacific and eastern tropical and subtropical South Pacific.

The patterns of SAV differ from the interannual variability (IAV) for parts of the oceans as shown in Supplement B (see Figs. B1b and B2b, respectively). There is high SAV and IAV in the North Atlantic. The equatorial Pacific shows relatively small SAV but large IAV caused by the ENSO, which op-

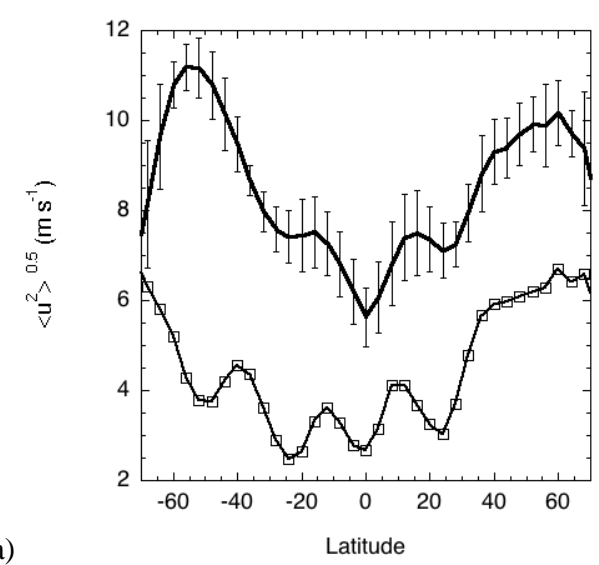

(a)

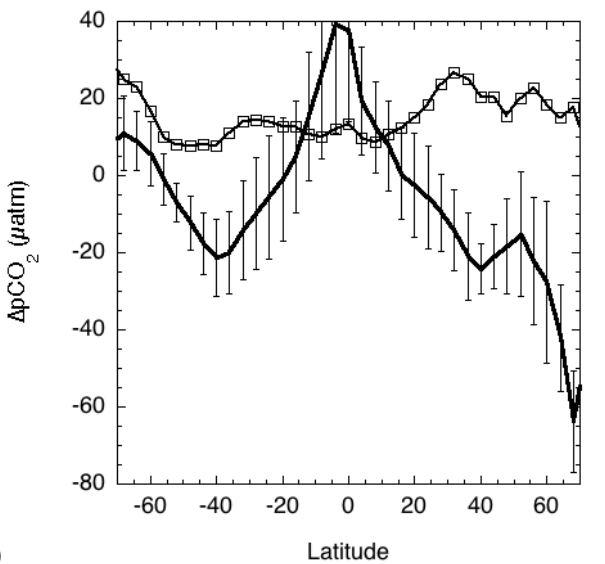

(b)

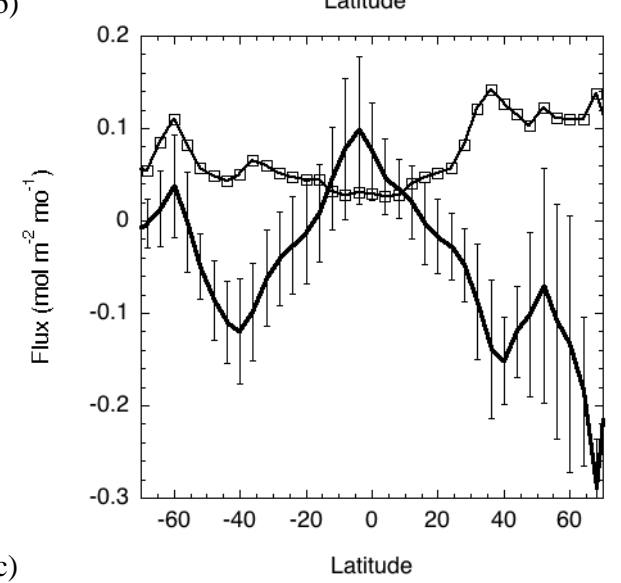

Fig. 9. Latitudinal distribution of zonal means (thick solid line) and standard deviations (spatial and temporal variability; thin solid line with squares) for the: (a) square root of the second moment $<U^{2}>^{0.5}$ of the $20 \mathrm{yr}$ monthly mean CCMP wind product; (b) $\Delta p \mathrm{CO}_{2}$ from the monthly Takahashi et al. (2009) climatology; and (c) the specific sea-air $\mathrm{CO}_{2}$ flux $\left[\mathrm{mol} \mathrm{m}^{2}\right.$ month $\left.^{-1}\right]$ computed by applying the $20 \mathrm{yr} C \mathrm{CMP}$ wind product to the Takahashi $p \mathrm{CO}_{2}$ climatology using Eq. (2). The error bars on the zonal means indicate the spatial variability (standard deviation) of means for the $5^{\circ}$ longitude bins in the particular latitude band.

erates on interannual timescales. For large parts of the subtropical gyres the ratio of IAV to SAV is small $(\approx<0.2)$, 
indicating that variability on seasonal timescales dominates (Fig. B3). In the equatorial and high latitude areas the ratio is greater than 0.4 and in places the ratio is greater than 1.0, indicating that IAV exceeds subannual changes. The regions with high IAV correspond with those strongly affected by climate reorganizations: the North Atlantic Oscillation (NAO) in the North Atlantic; the El Niño/Southern Oscillation (ENSO) in the equatorial Pacific and equatorial Indian Ocean; and the Southern Annual Mode (SAM) in the Southern Ocean.

The time span of this study of two decades is at the lower limit to quantify decadal trends. On first order, $p \mathrm{CO}_{2 \mathrm{w}}$ is expected to track atmospheric $p \mathrm{CO}_{2 \mathrm{a}}$ increases on longer timescales. The surface ocean is closely coupled with the lower atmosphere through rapid sea-air gas exchange and relatively slower exchange between the surface mixed layer and waters below. Longer-term secular trends in $\Delta p \mathrm{CO}_{2}$ can arise from changes in circulation and upwelling patterns, and associated changes in biological productivity. The trends are also impacted by the rapid rise in atmospheric $\mathrm{CO}_{2}$, finite uptake capacity of the surface mixed layer, and decreasing buffer capacity. In absolute sense, the amount of fossil fuel derived $\mathrm{CO}_{2}$ taken up by the ocean increases (Figs. 3a and 8). In a fractional sense, these factors can lead to a diminished uptake of anthropogenic $\mathrm{CO}_{2}$ (Fig. 3b).

The trend in the global annual flux for the empirical approach, not accounting for atmospheric $\mathrm{CO}_{2}$ increase, is $0.07 \pm 0.06\left(\mathrm{Pg} \mathrm{C} \mathrm{yr}^{-1}\right)$ decade $^{-1}$ over the last two decades (Fig. 10d). This decreasing uptake, in the absence of an atmospheric $\mathrm{CO}_{2}$ increase, suggests a strengthening of ocean $\mathrm{CO}_{2}$ sources or weakening of $\mathrm{CO}_{2}$ sinks, due to changes of $\triangle p \mathrm{CO}_{2}$ or wind speed. The second moment of the wind speed increases by $0.32 \pm 0.04\left(\mathrm{~m} \mathrm{~s}^{-1}\right)^{2}$ per year, which translates into about a $0.2 \mathrm{~m} \mathrm{~s}^{-1}$ increase per decade (Fig. 10a). Global SST as determined from the NOAA OI SST product (Reynolds et al., 2007) shows an increasing trend of $0.08 \pm 0.03\left({ }^{\circ} \mathrm{C} \mathrm{yr}^{-1}\right)$ decade $^{-1}$ (Fig. 10b). The trends in SST impact the $\Delta p \mathrm{CO}_{2}$ and wind will impact gas transfer in the P-10 approach. An analysis holding either the SST or wind constant in the P-10 approach indicates that the changes in the wind and SST can act synergistically or antagonistically on the trend in fluxes depending on the region. For example, at high northern latitudes the trends in winds and SST cause an increasing $\mathrm{CO}_{2}$ sink over the past two decades; in the equatorial Pacific the impact of winds and SST cause a larger $\mathrm{CO}_{2}$ source; while in the Southern Ocean, the change in $\triangle p \mathrm{CO}_{2}$ due to changing SST will decrease the sink while the winds work in an opposing fashion.

The global trends in sea-air $\mathrm{CO}_{2}$ flux from 1990-2009 are strongly influenced by significant IAV in $\triangle p \mathrm{CO}_{2}$ (Fig. 10c). In particular, the large El Niños in 1992/93 and 1998 decreased the equatorial $\Delta p \mathrm{CO}_{2}$ and, thus, have the net effect of increasing the globally integrated $\mathrm{CO}_{2}$ flux into the ocean (Fig. 10d). The changes in flux by these events are large enough to impact the trend over the 2 decades. Thus,
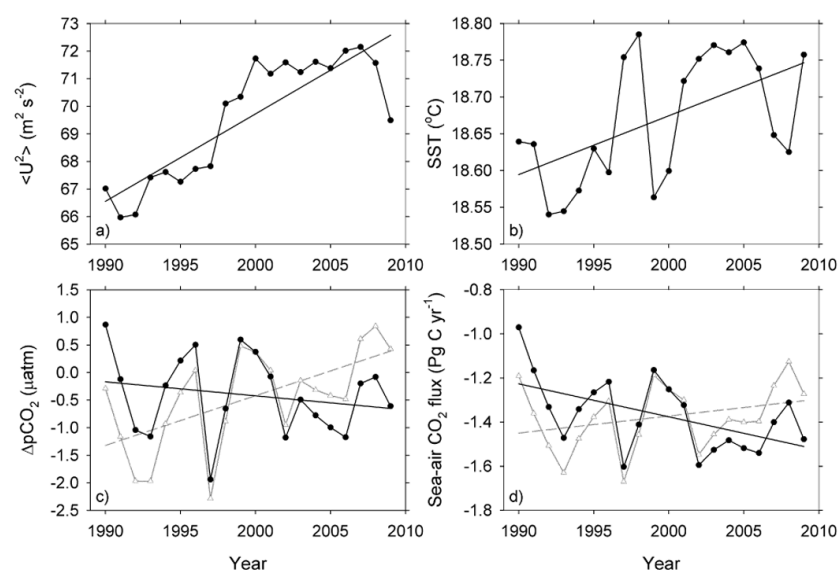

Fig. 10. $20 \mathrm{yr}$ global ocean trends in: (a) second moment of wind speed; (b) SST; (c) $\Delta p \mathrm{CO}_{2}$, assuming no atmospheric $\mathrm{CO}_{2}$ increase (gray line) and including atmospheric $\mathrm{CO}_{2}$ forcing (black line); and (d) globally integrated contemporary sea-air $\mathrm{CO}_{2}$ flux over the past two decades (1990-2009) without atmospheric $\mathrm{CO}_{2}$ forcing (gray line) and including atmospheric $\mathrm{CO}_{2}$ forcing (black line). The change in $\Delta p \mathrm{CO}_{2}$ is determined according to the procedures of Park et al. (2010a). The slopes for the linear regressions (solid line) for area-weighted $<U^{2}>$, SST, $\Delta p \mathrm{CO}_{2}$ and flux are $0.32 \pm 0.04\left(\mathrm{~m} \mathrm{~s}^{-1}\right)^{2} \mathrm{yr}^{-1} ; 0.08 \pm 0.03\left({ }^{\circ} \mathrm{C} \mathrm{yr}^{-1}\right)$ decade $^{-1}$; $-0.3 \pm 0.3\left(\mu \mathrm{atm} \mathrm{yr}^{-1}\right)$ decade $^{-1}$ including atmospheric $\mathrm{CO}_{2}$ forcing; and $-0.15 \pm 0.06\left(\mathrm{Pg} \mathrm{C} \mathrm{yr}^{-1}\right)$ decade $^{-1}$ including atmospheric $\mathrm{CO}_{2}$ forcing, respectively.

climate reorganizations on multiannual timescales have an appreciable impact on the trends over the 2 decades.

\subsection{Summary of global sea-air anthropogenic $\mathrm{CO}_{2}$ fluxes and trends in models}

The median sea-air anthropogenic $\mathrm{CO}_{2}$ fluxes for the different models for 1990-2009, provided in Table 3, show good agreement ranging from $-1.9 \mathrm{PgC}^{-1}$ to $-2.4 \mathrm{Pg} \mathrm{C} \mathrm{yr}^{-1}$ despite different approaches and constraints. The median values are centered on, or determined for, 2000, and they are within their estimated uncertainties. The approaches differ appreciably in their IAV, SAV and trend. The decadal trends differ by a factor of four. Approaches that implicitly or explicitly incorporate contemporary changes in physics and biogeochemistry show smaller increase in $\mathrm{CO}_{2}$ uptake than those that use ocean interior data. The latter methods assume a linear response of the ocean uptake to the atmospheric perturbation and constant ocean circulation. It is not possible to conclusively determine or attribute the best trend estimate given the methodological imperfections of each approach. While median uptakes for different methods agree, there are appreciable differences within each type of models. For example, in the OBGCMs differences of $\approx 1 \mathrm{Pg} \mathrm{C} \mathrm{yr}^{-1}$ (Fig. 6, Table A1) are due to different forcing, transport and representation of the ocean carbon cycle. Differences are also 
caused by more mundane issues that have been corrected for, such as estimates of global ocean surface area and conversion of areal representations, and different representations of sea ice. This is shown in Supplement A, where the outputs of the OBGCMs are normalized for area by determining the average flux in each of the 23 surface regions of the ocean inversion and then integrating over the area of each of the regions as provided in RECCAP; leading to adjustments up to $0.3 \mathrm{Pg} \mathrm{C}$ and better agreement between model runs.

Most models show trends of increasing anthropogenic $\mathrm{CO}_{2}$ uptake from 1990 to 2009 (or 2007). The median for the empirical approach, OBGCMs, and atmospheric inversions all show a consistent change in the anthropogenic $\mathrm{CO}_{2}$ uptake of -0.13 to $-0.15\left(\mathrm{PgC} \mathrm{yr}^{-1}\right)$ decade $^{-1}$ over the time period, which is the same as that inferred from the approach in $\mathrm{P}-10$ when including the atmospheric $\mathrm{CO}_{2}$ increases. Khatiwala et al. $(2009 ; 2012)$ estimate an increase of inventory change of $-0.35\left(\mathrm{Pg} \mathrm{C} \mathrm{yr}^{-1}\right)$ decade $^{-1}$ based on inventory changes in anthropogenic $\mathrm{CO}_{2}$ using a Green function formulated from transient tracers. By construction, the Green function approach uptake is smooth, monotonic over time, and proportional to the atmospheric $\mathrm{CO}_{2}$ increase.

\section{Conclusions}

An update of the sea-air $\mathrm{CO}_{2}$ flux based on the $\Delta p \mathrm{CO}_{2}$ climatology of Takahashi et al. (2009) (T-09), and the average 20 yr CCMP wind product, yields an anthropogenic $\mathrm{CO}_{2}$ flux of $-2.0 \mathrm{PgC} \mathrm{yr}^{-1}$ with an uncertainty of $0.6 \mathrm{PgC} \mathrm{yr}^{-1}$. This estimate includes adjustments for undersampling, coastal areas and riverine inputs. Using an empirical approach relating $\Delta p \mathrm{CO}_{2}$ to SST changes according to Park et al. (2010a) (P10) together with model output including the effect of increasing atmospheric $\mathrm{CO}_{2}$ levels suggests a decadal trend of $-0.15\left(\mathrm{Pg} \mathrm{C} \mathrm{yr}^{-1}\right)$ decade $^{-1}$. The trend indicates that the ocean sink was increasing over the past two decades. The results of this empirical approach are in good agreement with median anthropogenic $\mathrm{CO}_{2}$ uptake for 2000 and decadal trends for 6 OBGCMs of $-1.9 \mathrm{Pg} \mathrm{Cyr}^{-1}$ and -0.14 $\left(\mathrm{PgC} \mathrm{yr}^{-1}\right)$ decade $^{-1}$, and the median 12 atmospheric inversions of $-2.1 \mathrm{PgC} \mathrm{yr}^{-1}$ and $-0.13\left(\mathrm{PgC} \mathrm{yr}^{-1}\right)$ decade $^{-1}$. The anthropogenic $\mathrm{CO}_{2}$ uptake based on interior measurements shows a greater anthropogenic $\mathrm{CO}_{2}$ uptake, but within the uncertainty of other measurements. However, trends based on ocean interior carbon changes or tracer methods are significantly greater. The transient tracer based Green function approach of Khatiwala et al. $(2009,2012)$ yields an anthropogenic $\mathrm{CO}_{2}$ uptake of $-2.2 \mathrm{PgC} \mathrm{yr}^{-1}$ and a decadal trend of $-0.35\left(\mathrm{Pg} \mathrm{C} \mathrm{yr}^{-1}\right)$ decade $^{-1}$. Ocean inversions show an uptake for 2000 of $-2.4 \mathrm{Pg} \mathrm{C} \mathrm{yr}^{-1}$ and a prescribed trend of $-0.5\left(\mathrm{PgC} \mathrm{yr}^{-1}\right)$ decade $^{-1}$. As the ocean interior estimates reflect changes over longer timescales, the difference in trends for the different methods could be caused by the decreasing efficiency in ocean uptake with time. However, the trends for the P-10 method and OBGCMs over the two decades are influenced by IAV in sources and sinks, which do not show up in the ocean interior estimates.

\section{Supplementary material related to this article is available online at: http://www.biogeosciences.net/10/ 1983/2013/bg-10-1983-2013-supplement.pdf.}

Acknowledgements. We wish to thank Joaquin Triñanes for processing the CCMP wind data. RW, G-HP., RAF were supported in part through the Global Carbon Data Management and Synthesis Project of the NOAA Climate Program Office. NG and HG were supported by funds from ETH Zurich and through the FP7 projects CarboChange (Project reference 264879) and GeoCarbon. CS was supported by grants, NSF/OPP 0944761 and NOAA NA12OAR4310058. SCD acknowledges support through the NOAA Climate Process Team activity, NOAA grant NA07OAR4310098. CH and JS were supported through EU FP7 project COMBINE (grant agreement no. 226520), the Research Council of Norway funded project CarboSeason (185105/S30), the Norwegian Metacenter for Computational Science and Storage Infrastructure (NOTUR and Norstore, "Biogeochemical Earth system modeling" projects nn2980k and ns2980k) and the core project BIOFEEDBACK of the Centre for Climate Dynamics (SKD) within the Bjerknes Centre for Climate Research.

Edited by: C. Sabine

\section{References}

Andres, R. J., Boden, T. A., Bréon, F.-M., Ciais, P., Davis, S., Erickson, D., Gregg, J. S., Jacobson, A., Marland, G., Miller, J., Oda, T., Olivier, J. G. J., Raupach, M. R., Rayner, P., and Treanton, K.: A synthesis of carbon dioxide emissions from fossil-fuel combustion, Biogeosciences, 9, 1845-1871, doi:10.5194/bg-9-18452012, 2012.

Assmann, K. M., Bentsen, M., Segschneider, J., and Heinze, C.: An isopycnic ocean carbon cycle model, Geosci. Mod. Develop., 3, 143-167, 2010.

Atlas, R., Hoffman, R. N., Ardizzone, J., Leidner, S. M., Jusem, J. C., Smith, D. K., and Gombos, D.: A cross-calibrated multiplatform ocean surface wind velocity product for meteorological and oceanographic applications, Bull. Amer. Meteor. Soc., 92, 157174, doi:10.1175/2010BAMS2946.1, 2011.

Aumont, O. and Bopp, L.: Globalizing results from ocean in situ iron fertilization studies, Global Biogeochem. Cy., 20, GB2017, doi:2010.1029/2005GB002591, 2006.

Bender, M. L., Ho, D. T., Hendricks, M. B., Mika, R., Battle, M. O., Tans, P. P., Conway, T. J., Sturtevant, B., and Cassar, N.: Atmospheric $\mathrm{O}_{2} / \mathrm{N}_{2}$ changes, 1993-2002: Implications for the partitioning of fossil fuel $\mathrm{CO}_{2}$ sequestration, Global Biogeochem. Cy., 19, GB4017, doi:10.1029/2004GB002410, 2005.

Borges, A. V., Delille, B., and Frankignoulle, M.: Budgeting sinks and sources of $\mathrm{CO}_{2}$ in the coastal ocean: Diversity of ecosystems counts, Geophys. Res. Let., 32, L14601, doi:10.1029/2005GL023053, 2005. 
Buitenhuis, E. T., Rivkin, R. B., Sailley, S., and Le Quéré, C.: Biogeochemical fluxes through microzooplankton, Glob. Biogeochem. Cy., 24, GB4015, doi:10.1029/2009GB003601, 2010.

Cai, W.-J.: Estuarine and coastal ocean carbon paradox: $\mathrm{CO}_{2}$ sinks or sites of terrestrial carbon incineration, Ann. Rev. Mar. Sci., 3, 123-145, doi:10.1146/annurev-marine-120709-142723, 2011.

Canadell, J. G., Ciais, P., Gurney, K., Le Quéré, C., Piao, S., Raupack, M. R., and Sabine, C. L.: An international effort to quantify regional carbon fluxes, EOS Trans., 92, 81-88, 2011.

Chavez, F., Takahashi, T., Cai, W.-J., Friederich, G. E., Hales, B. E., Wanninkhof, R., and Feely, R. A.: Chapter 15. The Coastal Ocean in: The First State of the Carbon Cycle Report (SOCCR): The North American Carbon Budget and Implications for the Global Carbon Cycle, Report by the US Climate Change Science Program and the Subcommittee on Global Change Research, edited by: King, A. W., Dilling, L., Zimmerman, G. P., Fairman, D. M., Houghton, R. A., Marland, G., Rose, A. Z., and Wilbanks, T. J., National Oceanic and Atmospheric Administration, National Climatic Data Center, Asheville, NC, USA, 157166, 2007.

Conway, T. J., Tans, P. P., Waterman, L. S., Thoning, K. W., Kitzis, D. R., Masarie, K. A., and Zhang, N.: Evidence for interannual variability of the carbon cycle from the NOAA/CMDL global air sampling network, J. Geophys. Res., 99, 22831-22855, 1994.

Denning, A. S. and Fung, I. Y.: Latitudinal gradient of atmospheric $\mathrm{CO}_{2}$ due to seasonal exchange with land biota, Nature, 376, 240 243, doi:10.1038/376240a0, 2002.

Doney, S., Lindsay, K., Caldeira, K., Campin, J.-M., Drange, H., Dutay, J.-C., Follows, M., Gao, Y., Gnanadesikan, A., Gruber, N., Ishida, A., Joos, F., Madec, G., Maier-Reimer, E., Marshall, J. C., Matear, R. J., Monfray, P., Mouchet, A., Najjar, R., Orr, J. C., Plattner, G.-K., Sarmiento, J., Schlitzer, R., Slater, R., Totterdell, I. J., Weirig, M.-F., Yamanaka, Y., and Yool, A.: Evaluating global ocean carbon models: the importance of realistic physics, Glob. Biogeochem. Cy., 18, GB3017, doi:10.1029/2003GB002150, 2004.

Doney, S. C., Lima, I., Feely, R. A., Glover, D. M., Lindsay, K., Mahowal, N., Moore, J. K., and Wanninkhof, R.: Mechanisms governing interannual variability in the upper ocean inorganic carbon system and air-sea $\mathrm{CO}_{2}$ fluxes, Deep-Sea Res. II, 56, 640-655, 2009a.

Doney, S. C., Lima, I., Moore, J. K., Lindsay, K., Behrenfeld, M. J., Westberry, T.K., Mahowald, N., Glover, D. M., and Takahashi, T.: Skill metrics for confronting global upper ocean ecosystembiogeochemistry models against field and remote sensing data, J. Mar. Systems, 76, 95-112, doi:10.1016/j.jmarsys.2008.05.015, 2009b.

Fairall, C. W., Hare, J. E., Edson, J. B., and McGillis, W.: Parameterization and micrometeorological measurement of air-sea gas transfer, Bound.-Lay. Meteorol., 96, 63-105, 2000.

Feely, R. A., Takahashi, T., Wanninkhof, R., McPhaden, M. J., Cosca, C. E., and Sutherland, S. C.: Decadal variability of the air-sea $\mathrm{CO}_{2}$ fluxes in the equatorial pacific ocean, J Geophys. Res., 111, CO8S90 doi:10.1029/2005JC003129, 2006.

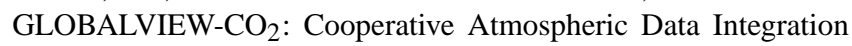
Project - Carbon Dioxide, CD-ROM, NOAA ESRL, Boulder, Colorado [Also available on Internet via anonymous FTP to ftp.cmdl.noaa.gov, Path:ccg/co2/GLOBALVIEW], 2011.
Graven, H. D., Gruber, N., Key, R., Khatiwala, S., and Giraud, $\mathrm{X}$.: Changing controls on oceanic radiocarbon: New insights on shallow-to-deep ocean exchange and anthropogenic $\mathrm{CO}_{2}$ uptake, J. Geophys. Res., 117, C10005, doi:10.1029/2012JC008074, 2012.

Gruber, N., Gloor, M., Fletcher, S. E. M., Doney, S. C., Dutkiewicz, S., Follows, M. J., Gerber, M., Jacobson, A. R., Joos, F., Lindsay, K., Menemenlis, D., Mouchet, A., Muller, S. A., Sarmiento, J. L., and Takahashi, T.: Oceanic sources, sinks, and transport of atmospheric $\mathrm{CO}_{2}$, Glob. Biogeochem. Cy., 23, GB1005, doi:10.1029/2008GB003349, 2009.

Ho, D. T., Law, C. S., Smith, M. J., Schlosser, P., Harvey, M., and Hill, P.: Measurements of air-sea gas exchange at high wind speeds in the Southern Ocean: Implications for global parameterizations Geophys. Res. Let., 33, L16611, doi:10.1029/2006GL026817, 2006.

Ho, D. T., Wanninkhof, R., Schlosser, P., Ullman, D. S., Hebert, D., and Sullivan, K. F.: Towards a universal relationship between wind speed and gas exchange: Gas transfer velocities measured with ${ }^{3} \mathrm{He}_{\mathrm{S}} \mathrm{SF}_{6}$ during the Southern Ocean Gas Exchange Experiment, J Geophys. Res., 116, C00F04, doi:10.1029/2010JC006854, 2011.

Ishidoya, S., Aoki, S., Goto, D., Nakazawa, T., Taguchi, S., and Patra, P. K.: Time and Space variations of $\mathrm{O}_{2} / \mathrm{N}_{2}$ ratio in the troposphere over Japan and estimation of the global $\mathrm{CO}_{2}$ budget for the period 2000-2010, Tellus B, 64, 18964,doi:10.3402/tellusb.v64i0.18964, 2012.

Ishii, M.: Sea-air $\mathrm{CO}_{2}$ flux in the Pacific Ocean for the period 19902009, Biogeosciences Discuss., in preparation, 2013.

Jackson, D. L., Wick, G. A., and Hare, J. E.: A comparison of satellite-derived carbon dioxide transfer velocities from a physically based model with GasEx cruise observations, J. Geophys. Res., 117, COOF13, doi:10.1029/2011jc007329, 2012.

Jacobson, A. R., Mikaloff-Fletcher, S. E., Gruber, N., Sarmiento, J. S., and Gloor, M.: A joint atmosphere-ocean inversion for surface fluxes of carbon dioxide: 1. Methods and global-scale fluxes, Glob. Biogeochem. Cy., 21, GB1019, doi:10.1029/2005GB002556, 2007.

Jahnke, R. A.: Chapter 16. Global Synthesis, in: Carbon and nutrient fluxes in continental margins, edited by: Liu, K.-K., Atkinson, L., Quinones, R., and Talaue-McManus, L., Springer, Heidelberg, 597-615, 2010.

Khatiwala, S., Primeau, F., and Hall, T.: Reconstruction of the history of anthropogenic $\mathrm{CO}_{2}$ concentrations in the ocean, Nature, 462, 346-349 doi:10.1038/nature08526, 2009.

Khatiwala, S., Tanhua, T., Mikaloff Fletcher, S., Gerber, M., Doney, S. C., Graven, H. D., Gruber, N., McKinley, G. A., Murata, A., Ríos, A. F., Sabine, C. L., and Sarmiento, J. L.: Global ocean storage of anthropogenic carbon, Biogeosciences Discuss., 9, 8931-8988, doi:10.5194/bgd-9-8931-2012, 2012.

Le Quéré, C., Rödenbeck, C., Buitenhuis, E. T., Conway, T. J., Langenfelds, R., Gomez, A., Labuschagne, C., Ramonet, M., Nakazawa, T., Metzl, N., and Gillett, N.: Saturation of the Southern ocean $\mathrm{CO}_{2}$ sink due to recent climate change, Science, 316, 1735-1738, doi:10.1126/science.1136188, 2007.

Le Quéré, C., Raupach, M. R., Canadell, J. G., Marland, G., Bopp, L., Ciais, P., Conway, T. J., Doney, S. C., Feely, R. A., Foster, P., Friedlingstein, P., Gurney, K., Houghton, R. A., House, J. I., Huntingford, C., Levy, P. E., Lomas, M. R., Majkut, J., Metzl, N., 
Ometto, J. P., Peters, G. P., Prentice, I. C., Randerson, J. T., Running, S. W., Sarmiento, J. L., Schuster, U., Sitch, S., Takahashi, T., Viovy, N., Werf, G. R. v. d., and Woodward, F. I.: Trends in the sources and sinks carbon dioxide, Nat. Geosci, 2, 831-836, doi:10.1038/ngeo689, 2009.

Le Quéré, C., Takahashi, T., Buitenhuis, E. T., Rödenbeck, C., and Sutherland, S. C.: Impact of climate change and variability on the global oceanic sink of $\mathrm{CO}_{2}$, Global Biogeochem. Cy., 24, GB4007, doi:10.1029/2009GB003599, 2010.

Lee, K., Wanninkhof, R., Takahashi, T., Doney, S., and Feely, R. A.: Low interannual variability in recent oceanic uptake of atmospheric carbon dioxide, Nature, 396, 155-159, 1998.

Lenton, A. and Matear, R. J.: Role of the southern annular mode (SAM) in Southern Ocean $\mathrm{CO}_{2}$ uptake, Global Biogeochem. Cy., 21, GB2016, doi:10.1029/2006GB002714, 2007.

Lenton, A., Metzl, N., Takahashi, T., Kuchinke, M., Matear, R., Roy, T., Sutherland, S. C., Sweeney, C., and Tilbrook, B.: The observed evolution of oceanic $p \mathrm{CO}_{2}$ and its drivers over the last two decades, Glob. Biogeochem. Cy., 26, GB2021, doi:10.1029/2011GB004095, 2012.

Lenton, A., Tilbrook, B., Law, R., Bakker, D., Doney, S. C., Gruber, N., Hoppema, M., Ishii, M., Lovenduski, N. S., Matear, R. J., McNeil, B. I., Metzl, N., Mikaloff Fletcher, S. E., Monteiro, P., Rodenbeck, C., Sweeney, C., and Takahashi, T.: Sea-air $\mathrm{CO}_{2}$ fluxes in the Southern Ocean for the period 1990-2009, Biogeosciences Discuss., 10, 285-333, doi:10.5194/bgd-10-285-2013, 2013

Li, Z., Adamec, D., Takahashi, T., and Sutherland, S. C.: Global aurocorrelation scales of the partial pressure of oceanic $\mathrm{CO}_{2}, \mathrm{~J}$ Geophys. Res., 110, C08002, doi:10.1029/2004JC002723, 2005.

Liu, K.-K., Atkinson, L., Quinones, R., and Talaue-McManus, L.: Carbon and nutrient fluxes in continental margins, Springer, Heidelberg, 741 pp., 2010.

Lovenduski, N. S., Gruber, N., and Doney, S. C.: Toward a mechanistic understanding of the decadal trends in the Southern Ocean carbon sink, Glob. Biogeochem. Cy., 22, GB3016, doi:10.1029/2007GB003139, 2008.

Manning, A. C. and Keeling, R. F.: Global oceanic and land biota sinks from the Scripps atmospheric oxygen flask sampling network, Tellus B, 95-116, 2006.

Matear, R. J. and Lenton, A.: Impact of historical climate change on the Southern Ocean carbon cycle, J. Clim., 21, 5820-5834, 2008.

Matsumoto, K., Sarmiento, J. L., Key, R. M., Aumont, O., Bullister, J. L., Caldeira, K., Campin, J. M., Doney, S. C., Drange, H., Dutay, J. C., Follows, M., Gao, Y., Gnanadesikan, A., Gruber, N., Ishida, A., Joos, F., Lindsay, K., Maier-Reimer, E., Marshall, J. C., Matear, R. J., Monfray, P., Mouchet, A., Najjar, R., Plattner, G. K., Schlitzer, R., Slater, R., Swathi, P. S., Totterdell, I. J., Weirig, M. F., Yamanaka, Y., Yool, A., and Orr, J. C.: Evaluation of ocean carbon cycle models with data-based metrics, Geophys. Res. Lett., 31, L07303, doi:10.1029/2003g1018970, 2004.

McKinley, G. A., Fay, A. R., Takahashi, T., and Metzl, N: Convergence of atmospheric and North Atlantic carbon dioxide trends on multidecadal timescales, Nat. Geosci, 4, 606-610, doi:10.1038/NGEO1193, 2011.

Metzl, N., Corbiere, A., Reverdin, G., Lenton, A., Takahashi, T., Olsen, A., Johannessen, T., Pierrot, D., Wanninkhof, R., Olafsdottir, S. R., Olafsson, J., and Ramonet, M.: Recent acceleration of the sea surface $f \mathrm{CO}_{2}$ growth rate in the North Atlantic subpo- lar gyre (1993-2008) revealed by winter observations, Glob. Biogeochem. Cy., 24, GB4004, doi:10.1029/2009GB003658, 2010.

Mikaloff Fletcher, S. E., Gruber, N., Jacobson, A. R., Doney, S. C., Dutkiewicz, S., Gerber, M., Follows, M., Joos, F., Lindsay, K., Menemenlis, D., Mouchet, A., Muller, S. A., and Sarmiento, J. L.: Inverse estimates of anthropogenic $\mathrm{CO}_{2}$ uptake, transport, and storage by the ocean, Glob. Biogeochem. Cy., 20, GB2002, doi:10.1029/2005GB002530, 2006.

Mikaloff Fletcher, S. E., Gruber, N., Jacobson, A. R., Doney, S. C., Dutkiewicz, S., Gerber, M., Gloor, M., Follows, M., Joos, F., Lindsay, K., Menemenlis, D., Mouchet, A., Müller, S. A., and Sarmiento, J. L.: Inverse estimates of the oceanic sources and sinks of natural $\mathrm{CO}_{2}$ and the implied oceanic transport, Global Biogeochem. Cy., 21, GB1010, doi:10.1029/2006GB002751, 2007.

Naegler, T.: Reconciliation of excess ${ }^{14} \mathrm{C}$-constrained global $\mathrm{CO}_{2}$ piston velocity estimates, Tellus B, 61, 372-384, 2009.

Nightingale, P. D., Malin, G., Law, C. S., Watson, A. J., Liss, P. S., Liddicoat, M. I., Boutin, J., and Upstill-Goddard, R. C.: In situ evaluation of air-sea gas exchange parameterizations using novel conservative and volatile tracers, Global Biogeochem. Cy., 14, 373-387, 2000.

Omar, A. M. and Olsen, A.: Reconstructing the time history of the air-sea $\mathrm{CO}_{2}$ disequilibrium and its rate of change in the eastern subpolar North Atlantic, 1972 - 1989, Geophys. Res. Let., 33, L04602, doi:10.1029/2005GL025425, 2006.

Park, G.-H., Wanninkhof, R., Doney, S. C., Takahashi, T., Lee, K., Feely, R. A., Sabine, C., Triñanes, J., and Lima, I.: Variability of global net sea-air $\mathrm{CO}_{2}$ fluxes over the last three decades using empirical relationships, Tellus, 62B, 352-368, doi:10.1111/j.1600-0889.2010.00498.x, 2010a.

Park, G.-H., Wanninkhof, R., and Triñanes, J.: Procedures to create near real-time seasonal air-sea $\mathrm{CO}_{2}$ flux maps, Atlantic Oceanographic and Meteorological Laboratory, NOAA Technical Memorandum-98, OAR AOML, Miami, 21 pp., 2010b.

Park, G.-H. and Wanninkhof, R.: A large increase of the $\mathrm{CO}_{2}$ sink in the western tropical North Atlantic from 2002 to 2009, J. Geophys. Res., 117, C08029, doi:10.1029/2011JC007803, 2012.

Pfeil, B., Olsen, A., Bakker, D. C. E., Hankin, S., Koyuk, H., Kozyr, A., Malczyk, J., Manke, A., Metzl, N., Sabine, C. L., Akl, J., Alin, S. R., Bellerby, R. G. J., Borges, A., Boutin, J., Brown, P. J., Cai, W. J., Chavez, F. P., Chen, A., Cosca, C., Fassbender, A. J., Feely, R. A., Gonzalez-Davila, M., Goyet, C., HardmanMountford, N., Heinze, C., Hood, M., Hoppema, M., Hunt, C. W., Hydes, D., Ishii, M., Johannessen, T., Jones, S. D., Key, R. M., Körtzinger, A., Landschutzer, P., Lauvset, S. K., Lefèvre, N., Lenton, A., Lourantou, A., Merlivat, L., Midorikawa, T., Mintrop, L., Miyazaki, C., Murata, A., Nakadate, A., Nakano, Y., Nakaoka, S., Nojiri, Y., Omar, A. M., Padin, X. A., Park, G. H., Paterson, K., Perez, F. F., Pierrot, D., Poisson, A., Rios, A. F., Santana-Casiano, J. M., Salisbury, J., Sarma, V. V. S. S., Schlitzer, R., Schneider, B., Schuster, U., Sieger, R., Skjelvan, I., Steinhoff, T., Suzuki, T., Takahashi, T., Tedesco, K., Telszewski, M., Thomas, H., Tilbrook, B., Tjiputra, J., Vandemark, D., Veness, T., Wanninkhof, R., Watson, A. J., Weiss, R., Wong, C. S., and Yoshikawa-Inoue, H.: A uniform, quality controlled Surface Ocean $\mathrm{CO}_{2}$ Atlas (SOCAT), Earth Syst. Sci. Data Discuss., 5, 735-780, doi:10.5194/essdd-5-735-2012, 2012. 
Reynolds, R. W., Smith, T. M., Liu, C., Chelton, D. B., Casey, K. S., and Schlax, M. G.: Daily high-resolution blended analyses for sea surface temperature, J. Clim., 20, 5473-5496, 2007.

Sabine, C. L. and Tanhua, T.: Estimation of anthropogenic $\mathrm{CO}_{2}$ inventories in the ocean, Annu. Rev. Mar. Sci., 2, 175-198, doi:10.1146/annurev-marine-120308-080947, 2010.

Sarmiento, J. L. and Sundquist, E. T.: Revised budget for the oceanic uptake of anthropogenic carbon dioxide, Nature, 356, 589-593, 1992.

Sarmiento, J. L., Gloor, M., Gruber, N., Beaulieu, C., Jacobson, A. R., Fletcher, S. E. M., Pacala, S., and Rodgers, K.: Trends and regional distributions of land and ocean carbon sinks, Biogeosciences, 7, 2351-2367, doi:10.5194/bg-7-2351-2010, 2010.

Schuster, U. and Watson, A. J.: A variable and decreasing sink for atmospheric $\mathrm{CO}_{2}$ in the North Atlantic, J. Geophys. Res., 112, C11006, doi:10.1029/2006JC003941, 2007.

Schuster, U., McKinley, G. A., Bates, N., Chevalier, F., Doney, S. C., Fay, A. R., Gonzalez-Davila, M., Gruber, N., Jones, S., Krijnen, J., Landschützer, P., Lefèvre, N., Manizza, M., Mathis, J. T., Metzl, N., Olsen, A., Rios, A. F., Rödenbeck, C., SantanaCasiano, J. M., Takahashi, T., Wanninkhof, R., and Watson, A. J.: An assessment of the Atlantic and Arctic sea-air $\mathrm{CO}_{2}$ fluxes, 1990-2009, Biogeosciences, 10, 607-627, doi:10.5194/bg-10607-2013, 2013.

Sweeney, C., Gloor, E., Jacobson, A. R., Key, R. M., McKinley, G., Sarmiento, J. L., and Wanninkhof, R.: Constraining global air-sea gas exchange for $\mathrm{CO}_{2}$ with recent bomb C-14 measurements, Glob. Biogeochem. Cy., 21, GB2015, doi:10.1029/2006GB002784, 2007.

Takahashi, T., Sutherland, S. G., Sweeney, C., Poisson, A. P., Metzl, N., Tilbrook, B., Bates, N. R., Wanninkhof, R., Feely, R. A., Sabine, C. L., Olafsson, J., and Nojjiri, Y.: Global sea-air $\mathrm{CO}_{2}$ flux based on climatological surface ocean $p \mathrm{CO}_{2}$, and seasonal biological and temperature effects, Deep-Sea Res. II, 49, 16011622, 2002.

Takahashi, T., Feely, R. A., and Wanninkhof, R.: Decadal change of the surface water $p \mathrm{CO}_{2}$ in the North Pacific: a synthesis of 35 years of observation, J. Geophys. Res., 111, doi:10.1029/2005JC003074, 2006.
Takahashi, T., Sutherland, S. C., Wanninkhof, R., Sweeney, C., Feely, R. A., Chipman, D. W., Hales, B., Friederich, G., Chavez, F., Sabine, C., Watson, A., Bakker, D. C. E., Schuster, U., Metzl, N., Inoue, H. Y., Ishii, M., Midorikawa, T., Nojiri, Y., Koertzinger, A., Steinhoff, T., Hoppema, M., Olafsson, J., Arnarson, T. S., Tilbrook, B., Johannessen, T., Olsen, A., Bellerby, R., Wong, C. S., Delille, B., Bates, N. R., and de Baar, H. J. W.: Climatological mean and decadal change in surface ocean $p \mathrm{CO}_{2}$, and net sea-air $\mathrm{CO}_{2}$ flux over the global oceans, Deep-Sea Res. II, 56, 554-577, doi:10.1016/j.dsr2.2008.12.009, 2009.

Telszewski, M., Chazottes, A., Schuster, U., Watson, A. J., Moulin, C., Bakker, D. C. E., González-Dávila, M., Johannessen, T., Körtzinger, A., Lüger, H., Olsen, A., Omar, A., Padin, X. A., Ríos, A., Steinhoff, T., Santana-Casiano, M., Wallace, D. W. R., and Wanninkhof, R.: Estimating the monthly $p \mathrm{CO}_{2}$ distribution in the North Atlantic using a self-organizing neural network, Biogeosciences, 6, 1405-1421, 2009, http://www.biogeosciences.net/6/1405/2009/.

Thompson, D. W. J. and Solomon, S.: Interpretation of recent Southern Hemisphere climate change, Science, 296, 895-899, doi:10.1126/science.1069270, 2002.

Wallcraft, A. J., Kara, A. B., Barron, C. N., Metzger, E. J., Pauley, R. L., and Bourassa, M. A.: Comparisons of monthly mean 10-m wind speeds from satellites and NWP products over the global ocean, J. Geophys. Res., 114, D16109, doi:10.1029/2008JD011696, 2009.

Wanninkhof, R.: Relationship between gas exchange and wind speed over the ocean., J. Geophys. Res., 97, 7373-7381, 1992.

Wanninkhof, R., Asher, W. E., Ho, D. T., Sweeney, C. S., and McGillis, W. R.: Advances in quantifying air-sea gas exchange and environmental forcing, Ann. Rev. Mar. Sci., 1, 213-244, doi:10.1146/annurev.marine.010908.163742, 2009.

Watson, A. J., Schuster, U., Bakker, D. C. E., Bates, N. R., Corbière, A., González-Dávila, M., Friedrich, T., Hauck, J., Heinze, C., Johannessen, T., Körtzinger, A., Metzl, N., Olafsson, J., Olsen, A., Oschlies, A., Padin, A., Pfeil, B., SantanaCasiano, J. M., Steinhoff, T., M.Telszewski, Rios, A. F., Wallace, D. W. R., and Wanninkhof, R.: Tracking the variable North Atlantic sink for atmospheric $\mathrm{CO}_{2}$, Science, 326, 1391-1393, doi:10.1126/science.1177394, 2009.

Young, I. R., Zieger, S., and Babanin, A. V.: Global trends in wind speed and wave height, Science, 332, 451-455, doi:10.1126/science.1197219, 2011. 